\title{
Earnings Performance Measures and CEO Turnover: Street versus GAAP Earnings
}

\author{
Henry JARVA* \\ Aalto University, Finland \\ Henry.Jarva@aalto.fi \\ Juha-Pekka KALLUNKI \\ University of Oulu, Finland \\ Stockholm School of Economics, Sweden \\ Aalto University, Finland \\ Juha-Pekka.Kallunki@oulu.fi \\ Gilad LIVNE \\ University of Exeter, United Kingdom \\ G.Livne@exeter.ac.uk
}

February 6, 2019

\begin{abstract}
* Corresponding author contact information: Tel.: +358 40701 5840; e-mail: henry.jarva@aalto.fi. We thank the workshop participants at Aalto University, Cass Business School, Hebrew University, LMU, the University of Exeter, the University of Leicester, University of Haifa, WHU, the 2014 Nordic Accounting Conference, the 2014 EAA Annual Meeting, and especially Eli Amir, Mark Bradshaw, Martin Jacob, Matti Keloharju, Sonia Konstandinidi, Per Olsson, Markku Rahiala, Sarayut Rueangsuwan, and anonymous reviewers for their helpful comments and suggestions. We thank Bianca Beyer, Topi Kämäräinen, and Ashish Khatri for research assistance. All remaining errors are ours.
\end{abstract}




\title{
Earnings Performance Measures and CEO Turnover: Street versus GAAP Earnings
}

\begin{abstract}
Prior research reports that analysts focus on street earnings, which are measures that typically exceed GAAP earnings. Using a sample of CEO turnovers from 1993-2016 we show that the likelihood and speed of forced CEO turnover - but not voluntary turnover - are higher when analysts exclude income-decreasing items. The association between exclusions and forced turnovers is particularly pronounced for high magnitude exclusions. We also show that greater street exclusion of income-decreasing items, the lower CEO bonus payouts. We find that boards use audited and more conservative GAAP earnings in evaluating and dismissing CEOs, except in the recent period of 2010-2016.
\end{abstract}

Keywords: Street earnings, Street exclusions, GAAP earnings, CEO turnover

JEL classification: G38, J41, K22, M41 


\section{Introduction}

The statutory purpose of financial statements is to provide decision-useful information to investors, lenders and creditors (FASB, 2010). Kothari et al. (2010) provide a more nuanced view by arguing that the principal role of the income statement is to measure firm performance for contracting, particularly with management, whereas the balance sheet primarily serves a stewardship role. Although firms are required to prepare income statement numbers using Generally Accepted Accounting Principles (GAAP), many analyst focus on a different performance measure colloquially known as 'street' earnings. These are analyst-adjusted measures of GAAP earnings that are also regularly tracked in commercial databases. Street earnings typically do not include certain non-recurring expense items that reduce reported profit (henceforth, street exclusions). Analysts and investors largely rely on street earnings rather than GAAP earnings (Bradshaw and Sloan 2002; Kolev et al. 2008; Ford 2016).

A number of papers examine the relationship between CEO turnover and firm performance (e.g., Murphy and Zimmerman, 1993; Engel et al., 2003; Bhagat and Bolton, 2008; Jenter and Kanaan, 2015; Ghosh and Wang, 2018). Although this literature finds consistently that CEO turnover is inversely related to firm performance, the relation is not strong (Brickley, 2003). A second strand of literature considers the persistence and relevance of non-recurring items that analysts often exclude from reported earnings for stock pricing (Bradshaw and Sloan, 2002; Burgstahler et al., 2002; Doyle et al., 2003; Marques, 2006; Dechow et al., 2014). ${ }^{1}$ Bushman et al.

\footnotetext{
${ }^{1}$ For example, Bhattacharya et al. (2003) find that street earnings are more persistent (and hence more informative for valuation purposes) than GAAP earnings. Bradshaw and Sloan (2002) and Dechow et al. (2014) show that street earnings are more closely associated with stock prices than with GAAP earnings.
} 
(2006) and Banker et al. (2009) provide theoretical arguments supported by empirical evidence from compensation data that the greater the value relevance ${ }^{2}$ of a performance measure, the greater its pay-performance sensitivity. The results reported in Bushman et al. (2006) and Banker et al. (2009) therefore suggest little role in CEO performance evaluation for street exclusions because analysts disregard them. ${ }^{3}$ Black et al. (2018) find that a small fraction of firms that use non-GAAP performance measures internally in compensation contracting also disclose these measures in earnings announcements. This finding suggests firms may be using different performance measures in internal communications vs. external communication. Consistent with this empirical insight, several papers have argued that measures used in stock market valuations could (and should) differ from measures used in internal decisions (Gjesdal 1981; Paul 1992; Bushman and Smith 2001; Wagenhofer 2009; Kothari et al. 2010). This suggests that even though street exclusions are not value relevant, they may still be used internally. In other words, one set of papers suggests that because street exclusions are valuation irrelevant, they should also be discounted by boards when deciding on CEO dismissals. On the other hand, other papers distinguish between value relevance and relevance for internal decision making. The implication is that street exclusions can (and should) be used internally, if they provide information about the quality of the CEO.

In this paper, we examine which set of the arguments discussed above is supported in the context of CEO retention decisions, because little is known whether numbers that are used by market participants, or GAAP numbers, are more relevant for internal corporate governance

\footnotetext{
${ }^{2}$ Value relevance refers to the information content of a variable that is relevant for the pricing of the stock.

${ }^{3}$ Neither paper, however, examines the role of analyst-produced performance measures.
} 
purposes, especially CEO retention decisions. Specifically, we contribute to this literature by examining whether the likelihood of a CEO dismissal is related to the exclusions that are largely ignored by analysts and investors for valuation purposes.

Our empirical results are derived from the intersection of ExecuComp, Compustat, CRSP, and I/B/E/S databases for the period from 1993 to 2016. Using a comprehensive sample of 2,635 CEO turnover events of which 716 are classified as forced turnover, our logistic regressions and proportional hazard analyses indicate that the likelihood and speed of forced CEO turnover - but not voluntary turnover - are positively related to street exclusions and, more generally, to GAAP earnings. The positive relation between street exclusions is stronger the larger the magnitude of analysts' exclusion of income-decreasing items. We obtain these results after controlling for a variety of factors, including a firm's pre-turnover performance, firm-specific characteristics, and governance variables. Therefore, the results suggest that the earnings measure used in CEO retention decisions (GAAP earnings) differs from the performance measure used by external parties for valuation purposes (street earnings).

We conduct several additional analyses to better understand this finding. First, although street exclusions are a measure based on analyst data provider information (such as I/B/E/S), they are possibly influenced by managers who routinely communicate with analysts. Managers can voluntarily disclose a closely related earnings measure, which is commonly known as non-GAAP earnings. ${ }^{4}$ Like street earnings, non-GAAP earnings tend to exclude income-decreasing items, but

\footnotetext{
${ }^{4}$ It is important to note that we are not examining whether CEOs' voluntary disclosures of non-GAAP earnings affects boards' retention decisions. We leave this issue for future research for two reasons. First, a large dataset of managerdisclosed non-GAAP earnings have not been widely available. Second, we want to examine how an EPS metric produced by professionals (namely, I/B/E/S), and used by investors, is associated with forced CEO turnover decisions.
} 
managers decide what is excluded. This voluntary disclosure has risen in recent years although it was much less common in the earlier years of our sample. Nevertheless, it stands to reason that communications from managers, either privately (in earlier years) or publicly (more recently), shape street earnings and analyst forecasts. One concern regarding such communications is that they are used opportunistically. In response to this concern, in March 2003, the Securities and Exchange Commission (SEC) introduced Regulation G, which restricts what managers can exclude from GAAP earnings; it establishes that only non-recurring items can be excluded. ${ }^{5}$ The SEC has further increased its attention to non-GAAP in 2010 when it issued a new set of Compliance and Disclosure Interpretations (C\&DIs) (Black et al., 2018). If the SEC interventions caused analysts to focus on non-recurring items when calculating street earnings, street exclusions may have become less value relevant after the introduction of Regulation G. We thus explore whether the relation between the magnitude of street exclusions and CEO turnover is driven by the pre-Regulation $\mathrm{G}$ period. We find evidence of a significant relation between forced CEO turnover and street exclusions also post-Regulation $\mathrm{G}$ period but not in the $\mathrm{C} \& \mathrm{DI}$ period. This may be related to Lev's (2018) argument that the usefulness of reported earnings has rapidly deteriorated particularly during the recent $2-3$ decades. While it is premature to make any definite claim, the pattern we document is alarming because the primary role of earnings is to reflect performance.

To further shed light on the role of street exclusions in the broader context of CEO performance evaluation, we run a third set of analyses applied to CEO bonus payouts. Gaver and

\footnotetext{
${ }^{5}$ Kolev et al. (2008) and Heflin and Hsu (2008) provide evidence that manager-disclosed exclusions are more transitory, infrequent, and smaller in magnitude following the introduction of Regulation G.
} 
Gaver (1998) provide evidence that CEO cash compensation is shielded from the effects of above the line losses. In contrast, we find that street exclusions are significantly associated with CEO bonus, a finding that holds in both pre- and post-Regulation $\mathrm{G}$ periods, but not in the C\&DI period. Taken together, our results suggest that boards use GAAP earnings in evaluating and disciplining CEOs and do not ignore the less valuation-relevant street exclusions with the exception of the most recent period.

One important contribution of this study is to show that when balancing between the potentially more value-relevant street earnings and the (typically) more conservative GAAP earnings, boards tend to rely on the latter. One possible explanation is that street exclusions, particularly large ones, are seen as a signal about future managerial performance because they contain information about past investment underperformance. Consistent with this "underperformance hypothesis", we provide evidence that street exclusions are primarily attributable to special items (that contain various types of asset write-offs). This result can also explain why CEOs avoid timely write-offs (Bartov et al., 1998; Alciatore et al., 2000; Hirschey and Richardson, 2002, Jarva 2009; Li and Sloan 2017). CEOs seem to face a trade-off between applying GAAP in a timely and unbiased manner to avoid costly scrutiny (Hazarika et al., 2012), and protecting their CEO position by delaying recognition of losses. Moreover, while guiding analysts to exclude reported losses can attract more internal scrutiny and thus increase the chance of a dismissal, this practice helps keep stock prices high, which is beneficial for managers' stock of their company's equity instruments. Managers therefore balance the dismissal risk against the wealth benefit of guiding street exclusions. There are two additional, but not mutually exclusive, explanations to our results. First, it is possible that boards, like analysts, understand that street 
exclusions in themselves are relatively unimportant. Still, we would expect to statistically establish a significant relation between dismissals and street exclusions, if exclusions are correlated with adverse private information that boards observe, but analysts (and researchers) do not. Second, using more conservative and reliable numbers—rather than the higher street earnings-likely helps boards gain legitimacy when making difficult retention decisions and deflect criticisms of their action.

The remainder of the paper is organized as follows. Section 2 discusses related research and develops the hypotheses. The research design is presented in Section 3. Section 4 describes the data and descriptive statistics. Section 5 provides the empirical results, and Section 6 concludes.

\section{Literature review and hypothesis development}

\subsection{Determinants of CEO turnover}

There is an extensive literature on the determinants of CEO turnover, which for brevity we succinctly summarize here. This literature documents the retention roles of accounting and stock return performance (e.g., Weisbach, 1988; Murphy and Zimmerman, 1993; Jenter and Kanaan, 2015; Ghosh and Wang 2018), industry-related factors such as homogeneity and competition (Parrino, 1997; DeFond and Park, 1999), internal and external monitoring mechanisms (e.g., Goyal and Park, 2002; Huson et al., 2001; Parrino et al., 2003; Bhagat and Bolton, 2008), firm-CEO matching (Eisfeldt and Khunen, 2013) and accounting irregularities and earnings management (Leone and Liu, 2010; Hazarika et al., 2012).

Both market-based and accounting-based performance measures are associated with CEOretention decisions. Engel et al. (2003) show that boards weigh accounting variables relatively 
more if they are measured more accurately. They also show that accounting variables become more retention relevant as stock prices become more variable and hence noisier for performance valuation purpose. This evidence extends similar findings from the compensation literature. Agency theory establishes that multiple performance indicators should be used in optimal contracting, as long as they are not perfectly correlated and in inverse relation to their precision (Banker and Datar, 1989; Holmstrom and Milgrom, 1991; and Baker et al., 1994). In addition to performance measures that are observed externally, boards may rely on variables that are only internally available (Hayes and Schaefer, 2000). Therefore, the externally observed performance measures that we examine here (e.g., street exclusions) could appear retention relevant in our analysis—not only because they are directly relevant to boards, but also because they are incrementally informative over other internally-observed variables.

\subsection{Street vs. GAAP earnings}

The literature on street earnings establishes several relevant findings. Bradshaw and Sloan (2002) report that the difference between GAAP earnings and street earnings has increased over time. They also show that managers "encourage" analysts to focus on the (higher) street earnings. ${ }^{6}$ Bradshaw and Sloan (2002) provide evidence that this effort is successful in that markets seem to respond to street earnings rather than GAAP earnings. This evidence is intriguing because experimental evidence (Frederickson and Miller, 2004) suggests that professional investors are not misled by street earnings that are higher than GAAP earnings. Instead, owing to cognitive bias,

\footnotetext{
${ }^{6}$ In the same vein, Bowen et al. (2005) provide evidence that managers stress more favorable non-GAAP metrics in press conferences.
} 
unsophisticated investors may over-value street earnings. Bhattacharya et al. (2007) provide empirical evidence that further supports this conjecture.

Managers prepare and communicate non-GAAP earnings (also known as pro forma earnings) with increased rates over time. Non-GAAP earnings are conceptually separate from street earnings because the former originate from managers and the latter are produced by analysts. Managers' definitions of non-GAAP earnings need not be identical to analysts' definition of street earnings (Bhattacharya et al., 2003). Yet, Bradshaw (2003) notes that in 65\% of the cases, pro forma earnings and street earnings are identical and that the two measures are highly correlated. ${ }^{7}$ More recently, Doyle et al. (2013) review the process by which I/B/E/S, managers and analysts communicate and reach a similar conclusion. Bentley et al. (2018) is the first to provide largesample evidence about the differences and similarities between managers' non-GAAP reporting and I/B/E/S's street earnings. Their evidence shows that managers' non-GAAP reporting agrees with I/B/E/S's street earnings 78.9 percent of the time. Taken together, this evidence suggests that analysts' formation of the measure of street earnings used in forecasts is shaped by managers' communication of alternative earnings measures. However, while analysts have produced street earnings for many years, pro-forma earnings appear in a much lower frequency and are not available for researchers in commercial databases such as Compustat.

Black et al. (2018) examine the consistency with which non-GAAP earnings are used internally, for compensation purposes, as well as externally to communicate with markets. They

\footnotetext{
${ }^{7}$ Christensen et al. (2011) reach a similar conclusion: exclusions from street earnings vary from firm to firm, and they are strongly influenced by what managers exclude from their pro forma earnings. Analysts' incentives to co-operate with managers may explain this finding (Lim, 2001).
} 
report that firms disclose non-GAAP earnings, either in the earnings announcement or proxy statement in about $50 \%$ of their sample. Only in $11 \%$ of the cases non-GAAP earnings appear in both statements. This suggests a small overlap between the use of non-GAAP in external communication and internal compensation decisions. They do not explore how non-GAAP earnings and exclusions from GAAP earnings influence CEO turnovers. ${ }^{8}$

It is important to recognize that communications between managers and analysts, either publicly through the release of non-GAAP measures, or through private channels, may be opportunistic because managers attempt to outperform these expectations. Several papers (e.g., Bartov et al., 2002; Isidro and Marques, 2013; Guillamon-Saorin et al., 2017) provide evidence consistent with "expectations management."

Our paper aims to explore whether the performance measures that parties external to the firm (i.e., analysts) use for valuation purposes are used in internal retention decisions. We are motivated by the tension between the arguments that suggest that a performance measure that is more value relevant is also used more heavily in evaluating CEOs (Bushman et al., 2006, and Banker et al. 2009) and the arguments that this need not be the case (Gjesdal 1981; Paul 1992; Bushman and Smith 2001; Wagenhofer 2009; Kothari et al. 2010). ${ }^{9}$

\subsection{Hypothesis development}

There is practically no evidence as to which earnings metrics affect turnovers, and only a handful of papers feature in the compensation literature upon which we can draw. Gaver and Gaver

\footnotetext{
${ }^{8}$ Their sample spans the 2009-2015 period, and is therefore much smaller than ours.

${ }^{9}$ Prior literature does not contrast earnings measures reported by firms and those used by analysts and in the context of CEO turnover.
} 
(1998) show that nonrecurring gains flow through compensation but losses do not. This suggests that managers are shielded from recognizing one-time losses. More recent evidence confirms this finding but also suggests that boards exclude special items from compensation contracts for financially distressed firms (Potepa, 2014). Banker et al. (2009) do not distinguish between recurring and non-recurring income items; rather, they show that boards rely more heavily on GAAP earnings than operating cash flows if earnings are also more value relevant. However, we acknowledge that the evidence from the compensation literature may not carry over fully to retention decisions for at least two reasons. First, firms' compensation committees typically set compensation contracts, while dismissal decisions are performed by boards whose responsibilities are broader (e.g., strategic decisions, communication with shareholders, etc.). Second, compensation contracts are explicitly written on observable numbers, but CEO retention is based more on an implicit contract between the board and the CEO. Nevertheless, the basic idea that boards should consult performance measures that are also used externally seems plausible in the context of dismissal decisions.

From a legal perspective, a manager can be fired without cause, which is often the case when boards lose trust in the former's ability to run the firm. ${ }^{10}$ Therefore, the option to dismiss a CEO without cause means that boards are free to rely on any performance measure (or a combination of measures) that they consider relevant. Hence, unlike compensation contracts, GAAP earnings do not carry any particular legal significance for a termination decision. From a theoretical perspective, the choice of a performance measure is determined by its accuracy and

\footnotetext{
${ }^{10}$ See, for example, The Wall Street Journal, "How to Fire a CEO,” 30 October 2006.
} 
correlation with unobservable managerial ability and effort (see, Engel et al., 2003). In making retention decisions, the board therefore may be particularly interested in street earnings because they are informative as to how sophisticated agents outside the firm view its performance.

However, boards may have a different view than investors about the accuracy and value relevance of street earnings. First, such disagreement may arise because street earnings are not audited while GAAP earnings are. Second, in dismissal decisions conservative boards likely prefer conservative performance measures. To the extent that street earnings provide a rosier picture of performance, when dismissing the incumbent CEO, boards may legitimize their decisions by referring to a lower performance measure that appears reliable and objective. This, in turn, helps boards defend against potential criticism (e.g., in the press, by analysts and possibly shareholders) and appear unbiased. More broadly, whether GAAP earnings are more indicative of CEO ability than street earnings in the eyes of boards remains an open question. Therefore, our null hypothesis is as follows:

H1: Street exclusions are unrelated to the likelihood and speed of forced CEO turnover.

Our second hypothesis relates to regulatory interventions by the SEC. In 2003 and following the enactment of the Sarbanes-Oxley Act in July 2002, the SEC put into force Regulation G, which concerns the measurement and voluntary reporting of non-GAAP earnings. This regulation requires firms that disclose non-GAAP earnings to provide a clear reconciliation of nonGAAP to GAAP earnings and prohibits the exclusion of recurring income items from non-GAAP earnings. 
In an early study, Marques (2006) documents that market reactions to items excluded from GAAP earnings in non-GAAP earnings are similar before and after Regulation G, which suggests that this regulation is ineffective. ${ }^{11}$ In a sample covering the post-regulation period, Doyle et al. (2013) find evidence indicating that firm managers calculate non-GAAP earnings opportunistically to meet or beat analysts' expectations (which are based on street earnings). In a closely related study, Heflin and Hsu (2008) find evidence suggesting that managers use nonGAAP earnings to generate good performance perceptions to a lesser extent after the regulation is enacted. Kolev et al. (2008) find that exclusions are more transitory following Regulation G. Interestingly, in recent years (and under more stringent regulation) the voluntary disclosure of nonGAAP earnings has increased significantly. ${ }^{12}$

Although street earnings and non-GAAP earnings are produced by different agents, Regulation $\mathrm{G}$ and C\&DI may have affected analyst-produced street earnings by focusing their attention on non-recurring items. If post-regulatory intervention analysts exclude more nonrecurring items than before, boards may also disregard street exclusions to a greater extent following stringent regulations. On the other hand, if boards use GAAP earnings to legitimize dismissal decisions, the retention-relevance of GAAP earnings is expected to remain the same. Therefore, whether the disclosure regulation changes have changed the retention relevance of street exclusions in the eyes of boards is an empirical question. We present our second hypothesis in null form:

\footnotetext{
${ }^{11}$ Consistent with this assertion, the SEC has been concerned about compliance with Regulation G for some time and has published several guidelines and clarifications since 2003, including the most recent set published in May 2016.

${ }^{12}$ Some estimates indicate that the percentage of S\&P 500 companies disclosing non-GAAP earnings increased from 72 percent in 2009 to 90 percent in 2016 (Ford, 2016).
} 
H2: Street exclusions are unrelated to the likelihood of forced CEO turnovers in different subperiods.

\section{Research design}

\subsection{CEO turnover model}

We use logistic regressions to examine the relation between the earnings-based performance measures and the likelihood of CEO turnover. The dependent variable is the probability of CEO turnover. Following Hazarika et al. (2012), we distinguish between forced and voluntary turnover, but in the interest of brevity, we do not specify this in the notation. A turnover event is identified if the CEO in one year is different from the CEO in the preceding year. Consistent with prior studies (e.g., Hazarika el al. 2012), we use year $t$-1 performance measures to predict turnover in year $t$. This approach also overcomes the possibility a new CEO might take an earnings bath affecting year $t$ performance measures (Pourciau, 1993; Murphy and Zimmerman, 1993; Denis and Denis, 1995).

Our logistic model can be expressed as follows:

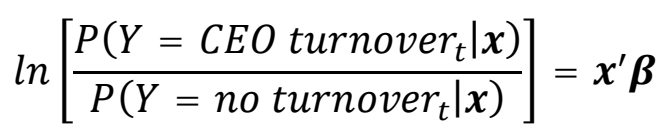

where $\boldsymbol{x}^{\prime}$ is a vector of explanatory variables and $\boldsymbol{\beta}$ is a vector of parameters. More specifically,

$$
\begin{aligned}
\boldsymbol{x}^{\prime} \boldsymbol{\beta}= & \beta_{1} \text { Performance }_{t-1}+\beta_{2} \text { For }_{-} \text {Rev }_{t-1}+\beta_{3} \text { Ret_Idio }_{t-1} \\
& +\beta_{4} \text { Ret_Peer }_{t-1}+\beta_{5} \text { Std_Ret }_{t-1}+\beta_{6} \text { LogMVE }_{t-1}+\beta_{7} M T B_{t-1} \\
& +\beta_{8} \text { SGR }_{t-1}+\beta_{9} L e v_{t-1}+\beta_{10} \text { CEO_Age } e_{t-1}+\beta_{11} \text { CEO_Owner } \\
& +\beta_{12} \text { CEO_Dual } \\
&
\end{aligned}
$$


We use three variants of the earnings-based performance measure (Performance), which is the main variable of interest: GAAP earnings per share (EPS_GAAP), street earnings per share as provided by I/B/E/S (EPS_Street), and street exclusions—-the difference between GAAP earnings and street earnings (Exclusions) — all of which are scaled by the lagged stock price. The use of I/B/E/S actual earnings as a proxy for street earnings is in line with previous research (e.g., Bradshaw and Sloan, 2002; Doyle et al., 2013; Kolev et al., 2008).

We control for several other firm-specific characteristics that have been shown to be related to CEO turnover based on the previous literature (e.g., Bhagat and Bolton, 2008). First, because exclusions affect analyst earnings forecasts, we control for revisions in analysts' earnings estimates (For_Rev), which refer to the last consensus forecast during the fiscal year minus the consensus forecast three months after the end of the previous fiscal year scaled by the lagged stock price. ${ }^{13}$ We decompose stock returns into idiosyncratic and industry components (Ret_Idio and Ret_Peer, respectively) because Jenter and Kanaan (2015) argue that boards of directors should ignore the components of firm performance that are caused by factors beyond the CEO's control. We expect that lower idiosyncratic return increases the probability of turnover. We also include a measure of firm risk (Std_Ret), computed as the standard deviation of the firm's monthly stock returns over a twelve-month period. Parrino et al. (2003) and Bushman et al. (2010) show that higher return volatility increases the likelihood of CEO turnover. We control for firm size as measured by the logarithm of the market value of equity ( $\log M V E)$. Following Hazarika et al. (2012), we control

\footnotetext{
${ }^{13}$ It can also serve as a proxy for the board's expectations (Farrell and Whidbee, 2003), or managerial guidance.
} 
for growth opportunities using the market-to-book ratio $(M T B)$, for the current growth rate using sales growth $(S G R)$, and for the capital structure using debt leverage (LEV).

We control for three CEO characteristics. First, Brickley (2003) argues that the age of the CEO is more important in explaining CEO turnover than measures of firm performance. Therefore, we include the CEO's age (CEO_Age) in our model. The next two variables, the CEO's share ownership (CEO_Owner) and a dummy variable indicating whether the CEO is also the board chair (CEO_Dual) are our firm governance-related measures. Finally, we include year and industry indicators (year effects and industry effects, respectively) to control for possible time and industry effects, respectively. Full details on the definitions of these variables are provided in the Appendix.

\subsection{Time-to-turnover model}

As an alternative to Model 2, we examine the likelihood of CEO turnover using Cox proportional hazard model estimation (see e.g., Hazarika et al., 2012). Unlike logistic regression, the Cox proportional hazard model explicitly accounts for the right-censoring that is prevalent in survival (or duration) time data. Specifically, sample censoring occurs because the follow-up period ends at the end of 2016, before all cases of CEO turnover occur. A second more important difference is that the dependent variable is the number of years that the CEO is in office. The Cox proportional hazard model can be expressed as follows:

$$
h(t \mid \boldsymbol{x}(t))=h_{\text {CEO turnover }}(t) \exp \left[\boldsymbol{x}^{\prime} \boldsymbol{\beta}\right]
$$

where $h(t)$ is the hazard rate; $x(t)$ is the same vector of time-varying covariates as in the logistic model; and $\boldsymbol{\beta}$ is a vector of parameters to be estimated. The hazard function in (3) is the product 
of two functions. The function $h_{\text {CEO turnover }}(t)$ characterizes how the hazard function changes as a function of survival time, while the other function, $\exp \left[\boldsymbol{x}^{\prime} \boldsymbol{\beta}\right]$, characterizes how the hazard function changes as a function of subject covariates (Hosmer and Lemeshow, 1999). All independent variables are the same as those in the logistic model, so we do not repeat them here.

\subsection{Determinants of exclusions}

In order to understand what may influence street exclusions, we use two approaches to provide evidence regarding which income statement items analysts exclude from GAAP earnings. First, following Doyle et al. (2003) and Kolev et al. (2008), we simply decompose exclusions into special items and other exclusions. Second, we use the earnings decomposition framework of Donelson et al. (2011) to develop a model that estimates normal and abnormal exclusions. The dependent variable is Exclusions, and the explanatory variables are expense line items in the income statement, including the cost of goods sold (COGS); sales, general and administrative expenses (SGA); depreciation and amortization (Depr); tax expenses (Tax); special items (SI); and all other expenses (Other). All the variables are deflated by the beginning-of-period market value of equity. Equation (4) is estimated for each industry based on the Fama and French 48-industry classification. Specifically, our measure of normal (abnormal) exclusions is the fitted (residual) value from the following cross-sectional model:

$$
\begin{gathered}
\text { Exclusions }_{t-1} \alpha_{0}+\alpha_{1} \text { COGS }_{t-1}+\alpha_{2} \text { SGA }_{t-1}+\alpha_{3} \text { Depr }_{t-1}+\alpha_{4} \text { Tax }_{t-1} \\
=+\alpha_{5} \text { SI }_{t-1}+\alpha_{6} \text { Other }_{t-1}+\varepsilon
\end{gathered}
$$

\section{Sample and descriptive statistics}


Our data come from four sources: ExecuComp for CEO data, the Center for Research on Securities Prices (CRSP) for stock returns data, Compustat for accounting data, and I/B/E/S for analyst data. We first identify all cases of CEO turnover for the sample period from 1993 to $2016 .^{14}$ In line with prior research (e.g., Engel et al. 2003; Eisfeldt and Kuhnen, 2013), we record a turnover event if the CEO identifier (i.e., the executive who holds the annual CEO flag) in year $\mathrm{t}$ is different from the CEO identifier in year $\mathrm{t}-1$. The new CEO may prefer to report low earnings in their first year to shield future income. Therefore, consistent with Hazarika et al. (2012), we exclude the CEOs who serve only an interim period (i.e., less than a year) in office to minimize any influence from earnings "big-bath" on our results. Following prior research, we eliminate utilities (SIC 4400-4999) and financial (SIC 6000-6999) industries. We also eliminate firm-year observations with insufficient data to compute the primary variables used in our tests.

Identifying whether a CEO's departure is forced or voluntary requires an inspection of press releases because forced turnover is often presented as retirement. Using a hand-collected sample of press releases, we classify each CEO turnover event as forced or voluntary based on information in the related news announcement. Specifically, following prior studies (Parrino 1997; Huson et al., 2001; Fich and Shivdasani, 2006; Bushman et al. 2010; Hazarika et al. 2012), turnover is classified as forced if (i) the CEO retires or resigns under questionable circumstances or the company fires, demotes, or forces the CEO out of the position (e.g., due to policy differences); (ii) the departing CEO is younger than 65 and the announcement does not report the reason as death,

\footnotetext{
${ }^{14}$ We begin our sample period in 1993 because data on the ExecuComp variable CEOANN (which indicates whether the executive served as CEO for all or most of the indicated fiscal year) are available from 1993.
} 
poor health, or the acceptance of another position, ${ }^{15}$ or (iii) the CEO retires but leaves the job within six months of the retirement announcement and does not take a comparable position elsewhere.

Our final sample contains 26,571 firm-year observations from 1993 to 2016. Of the total sample of 2,635 CEO turnovers, $716(27.2 \%)$ are forced. The sample size compares favorably with that of the recent study of Eisfeldt and Kuhnen (2013). Table 1 reports the distribution of these observations over the years. The results show that the number of observations varies over time and that the average turnover rate is $10.0 \%$ for all firm-year observations implying an average CEO tenure of 10 years. However, in the more recent period since 2010, total CEO turnover have somewhat increased.

[Insert Table 1 here]

Table 2 and Figure 1 present the means and standard deviations of GAAP earnings per share $\left(E P S \_G A A P\right)$, non-GAAP earnings per share (EPS_Street) and the exclusion of GAAP earnings per share during the year (Exclusions) for each year in the sample period. The mean value of EPS_GAAP is lower than the mean value of EPS_Street in all years except in 1994 and 1995. EPS_GAAP is negative in 2002 (the dot.com crisis) and 2008 (the great financial crisis), but EPS_Street is positive in all years. The standard deviations of EPS_GAAP, EPS_Street, and Exclusions move in tandem. The mean values for Exclusions are negative in 22 years out of 23. It also evident that mean values of Exclusions has become more negative over time. For example, the average exclusion from 1993-1997 is -0.005 , whereas the average for 2012-2016 is -0.023 .

\footnotetext{
${ }^{15}$ Many papers use the age of 60 years as a threshold.
} 
This finding is consistent with analysts' exclusion of income-decreasing items, a trend that increases during our sample period. Untabulated statistics reveal that GAAP and street EPS differ by at least one (ten) cent(s) for 85.6 (56.5) percent of the sample. At least a one-dollar difference can be found for 24.3 percent of the sample. In sum, the magnitude of street exclusions is substantial relative to GAAP earnings, especially during financial-turmoil periods.

[Insert Table 2 here]

[Insert Figure 1 here]

Table 3 reports the descriptive statistics for the variables used in the analyses for three subsamples of firm-years: forced turnovers, voluntary turnovers, and no turnovers. $T$-tests and Wilcoxon signed rank tests (both two-tailed) are performed by comparing whether performance measures of forced turnover sub-sample are significantly different from performance measures of voluntary and no turnover sub-samples. Table 3 shows that observations with forced CEO turnover are associated with poorer performance in the year before forced turnover than in other two groups. Specifically, in the forced turnover subsample, mean and median values of EPS_GAAP, EPS_Street, Ret_Idio, Ret_Peer, MTB, and SGR are significantly lower than those in the control sample. The mean (median) Exclusions is $-0.034(-0.003)$ for forced turnovers, compared to $0.022(0.000)$ for voluntary turnovers and $-0.016(0.000)$ for the no turnover sample. In other words, firms that dismiss their CEOs have significantly more negative street exclusions than firms whose CEOs leave voluntarily or firms that do not change CEOs. Firm governance variables (CEO_Age, CEO_Owner, and CEO_Dual) are also significantly different between the subsamples. On average, the CEOs in the forced turnover sub-sample are younger, hold less equity 
and have lower CEO-chairman duality rates compared voluntary turnovers. In sum, turnover firmyears differ from non-turnover firm-years along several performance dimensions; they are associated with lower GAAP earnings, lower stock returns, greater returns volatility, lower growth expectations, younger CEOs and stronger CEO power (as measured by CEO-chairman duality).

[Insert Table 3 here]

Table 4 reports the Pearson and Spearman correlations between the variables. For brevity, we discuss the Pearson correlations. EPS_GAAP and EPS_Street have a correlation coefficient of 0.593. Exclusions are positively correlated with EPS_GAAP (0.468), implying that higher GAAP earnings are associated with less negative exclusions. Exclusions are negatively correlated with EPS_Street (-0.364). Exclusions are positively correlated with For_Rev, Ret_Idio and Ret_Peer. Although the correlations are modest, they suggest that analysts exclude more expenses when market performance is poor. Unsurprisingly, better-performing firms receive higher valuations, as indicated by the positive correlation between $L o g M V E$ and accounting (EPS_GAAP and SGR) and stock market performance variables (Ret_Idio and Ret_Peer). Negative correlation between Std_Ret and LogMVE indicate that riskier companies have lower valuations. Finally, CEO_Age and CEO_Dual have small positive correlations with the two earnings measures.

[Insert Table 4 here]

\section{Empirical results}

\subsection{Street exclusions and CEO turnover}

Table 5 presents the results of our multinomial logistic analysis of the relation between CEO turnover and our variables of interest. We examine three models. In Model (1), GAAP 
earnings are the main variable of interest. We find that the probability of forced CEO turnover, but not voluntary turnover, is negatively related to GAAP earnings, as indicated by the negative and highly significant coefficient for EPS_GAAP in Model (1). Therefore, these results indicate that GAAP earnings play an important role in a board's decision to dismiss its CEO.

In Model (2), street earnings replace GAAP earnings as the main variable of interest. The results for Model (2) in Table 5 show that EPS_Street also has a significant negative relation to forced CEO turnover in the subsequent year. An untabulated Vuong (1987) test shows that Model (1) is significantly better in explaining forced turnovers than Model (2). In Model (3), we include both street earnings and street exclusions-the sum of which is GAAP earnings. Both are negatively related to the incidence of forced turnover, which is consistent with the results of Model (1), as both components add up to GAAP earnings. Model (3) thus confirms that both street exclusions and street earnings are similarly associated with turnover.

For forced CEO ousters, an inspection of the control variables suggests that firms with greater return volatility are more likely to change the CEO. The (untabulated) odds-ratio is highest for Std_Ret, followed by EPS_GAAP and Ret_Idio. Size, growth opportunities and leverage, as measured by $L o g M V E, S G R, M T B$ and $L E V$, play no role in forced turnovers. Consistent with Bhagat and Bolton (2008), forced turnover is less likely if the CEO holds a greater equity stake. Finally, CEO_Dual, a measure of CEO power, is not significantly associated with turnovers. The lack of significance may be explained by Brickley et al. (1997), who argue that it is not theoretically obvious which leadership structure is best. Finally, the coefficient on CEO age is negative in the forced sub-sample but positive in the voluntary sub-sample. This result is consistent 
with the findings of Engel et al. (2003). This indicates that older CEOs tend to resign, whereas boards regard age as a positive personal trait (because it is likely correlated with experience), so they do not tend to dismiss older executives.

[Insert Table 5 here]

We next assess the effect of our variables of interest on the duration of CEO employment using time-to-event analysis, as outlined in equation 3. We employ the Cox proportional hazard model. Note that a positive coefficient implies a larger hazard rate or a shorter "survival" rate. Structured in a similar way to Table 5, Table 6 reports the results of this analysis. Model (1) confirms that higher GAAP earnings are associated with longer service periods. The coefficient for street earnings on a standalone basis is insignificant in Model (2), implying this external measure of performance, on its own, is unrelated to forced turnovers. The results in Model (3) again suggest that boards use both street earnings and exclusions in CEO turnover decisions because both are significantly negative at the $1 \%$ level. The control variables also largely feature similar relations to those reported in Table 5.

[Insert Table 6 here]

Taken together, Tables 5 and 6 provide evidence that pertains to our first hypothesis. Specifically, we reject $\mathrm{H} 1$ as we find that GAAP earnings and street exclusions are associated with CEO turnover. In particular, street exclusions of expenses are associated with a higher probability of forced CEO turnover and shorter service periods.

\subsection{Regulatory changes}


In this section, we provide evidence pertaining to our second hypothesis. Recall that the 2003 Regulation G likely focused analyst attention on non-recurring items. Against this background, Panel A of Figure 1 does not provide compelling evidence that the gap between GAAP earnings and street earnings has progressively decreased since Regulation G was introduced. Next, we repeat the analysis conducted in Table 5 to examine whether our results differ by time period. If street exclusions become less valuation relevant after Regulation G, we expect to find that their association with forced turnover is weaker than that before 2003. Therefore, we re-run Model (3) in Table 4, but we now allow the coefficients of interest to vary between the preand post-Regulation G periods (i.e., 1993-3/2003 vs. 4/2003-2016).

Panel A of Table 7 provides the results for two different time periods. The results show that Exclusions continue to be significantly and negatively related to forced turnover in both PreRegulation G and Post-Regulation G periods, albeit with lower magnitude and significance in the post-Regulation G period. As a result, we reject Hypothesis 2 that street exclusions are unrelated to forced CEO turnover decisions in different sub-periods. The coefficient on EPS_Street is marginally significant in the pre-Regulation G period but highly significant in the post-Regulation period. Because GAAP earnings are the sum of street earnings and street exclusions, this evidence suggests that GAAP earnings play an important role in both periods (also confirmed by untabulated tests).

\section{[Insert Table 7 here]}

We further analyze the post-Regulation G period, distinguishing between 4/2003-2009 and the C\&DI period of 2010-2016. We report in Panel B of Table 7 that both (neither), street earnings 
nor exclusions are related (unrelated) to forced CEO turnovers in the first (second) period. ${ }^{16}$ One possible explanation for this surprising finding is related to the deterioration in the usefulness of GAAP reporting for both investors and executives that has accelerated in recent years (Bushman et al., 2016; Lev, 2018). This trend may explain both why managers resort more frequently to nonGAAP in recent years (Ford, 2016) and the increased enforcement of non-GAAP. Our finding could be therefore picking up this recent "breakdown" in financial reporting, which in turn, may have caused boards to increasingly rely on non-earnings measures (GAAP or otherwise). An interesting question for future research is whether this phenomenon is a temporary in nature or a more permanent development.

An inspection of the control variables indicates that-for Ret_Idio and CEO_Age-the effect is the same in all periods. However, for a few control variables, the sign or significance level changes. For example, Std_Ret, becomes insignificant after 2003, whereas CEO_Owner becomes negative and significant after 2003.

\subsection{Determinants of street exclusions and their association with CEO turnover}

The analyses above indicate that street exclusions are used in CEO retention decisions, with the exception of the most recent period. In this part of our investigation, we seek to provide evidence on the determinants of analysts' exclusions. Recall that street earnings tend to exclude income-decreasing items from GAAP earnings (as Table 3 indicates), which implies that certain expense types are associated with street exclusions. However, I/B/E/S does not provide a precise

\footnotetext{
${ }^{16}$ This finding also holds for CEO bonus payouts. Specifically, untabulated analysis shows that street earnings and street exclusions are significantly positive in pre- and post-Regulation $\mathrm{G}$ periods but not in the C\&DI period.
} 
formula as to what analysts exclude for each firm-year. Instead, we follow a statistical approach as outlined in equation 4 whereby exclusions are regressed on a number of expense line items in the income statement.

Panel A of Table 8 reports the descriptive statistics for these line items. All variables are deflated by the beginning-of-period market value of equity. The largest expense item is COGS (with mean value of -1.038), followed by SGA and Depr (mean values are -0.258 and -0.059 , respectively). The smallest expenses are $S I$, Other, and $T A X$. Although small in magnitude, special items represent accounting charges that are not expected to reoccur and are related to losses recognized in the current period with respect to past investments. The implication, therefore, is that they are indicative of managerial investment skill and talent. Panel B reports the results of the estimation of equation 4 by Fama-French 48 industry groups to control for normal exclusions in each industry. The findings indicate that the exclusions strongly relate to $S I$ and, to a much lesser extent to Other. The mean (median) coefficient estimate of $0.968(0.885)$ indicate that an almost one-to-one mapping exists between exclusions and special items. The model explains on average about $40.7 \%$ of the variation in Exclusions. While this result indicates a good explanatory power for the model, it also suggests that the source of exclusions relates to other factors, so exclusions are not identical across firm-years.

Panel C of Table 8 reexamines the relation between CEO turnover and street exclusions in two ways. First, we explore whether the turnover event is more sensitive to unusual (or abnormal) exclusions because boards may view abnormally high exclusions more cautiously (i.e., as less informative). We estimate abnormal exclusions using the residual obtained from the regression reported in Panel B. Therefore, normal exclusions are estimated using the regression line. Model 
(1) of Panel $\mathrm{C}$ reports the results of this procedure. Both Normal_Exclusions and Abnormal_Exclusions, are negatively related to forced CEO turnover. Second, since exclusions are closely associated with special items, the likelihood of CEO turnover may be higher when exclusions are special items. We test this assertion in Model (2), reported in Panel C. Specifically, we divide exclusions into two components: special items (SI) and other exclusions (Other Exclusions). The results indicate that both SI and other exclusions are negatively related to CEO turnover. This result, combined with the previous analyses, indicates that boards do not shield CEOs from the consequences of reporting large special items when making dismissal decisions.

[Insert Table 8 here]

\subsection{Bonus compensation and street exclusions}

Our finding that street exclusions are associated with forced turnover events is consistent with the notion that boards regard street exclusions as an internal performance measure, even if market participants may not use it for valuation purposes. Boards also use performance measures to set executive compensation schemes and reward good performance. Therefore, we examine whether street exclusions are associated with cash bonuses. It is reasonable to expect that CEOs' bonuses are based on the same earnings measures that boards use when replacing CEOs, because bonuses are designed to set targets for a CEO and a CEO will eventually be replaced if these targets are not met. Therefore, we regress the logarithm of one plus the cash bonus on the same independent variables as those used in the previous models, but the independent are not lagged. ${ }^{17}$

\footnotetext{
${ }^{17}$ Our assumption is that variables affecting the retention decision also affect annual bonus schemes. Therefore we use the same independent variables as in the turnover model.
} 
We investigate the relation between bonus and EPS_Street and Exclusions by estimating the following Tobit regression from our data:

$$
\begin{aligned}
\log (1+\text { Bonus })= & \beta_{0}+\beta_{1} \text { Performance }+\beta_{2} \text { For_Rev }+\beta_{3} \text { Ret_Idio } \\
& +\beta_{4} \text { Ret_Peer }+\beta_{5} \text { Std_Ret }+\beta_{6} L o g M V E+\beta_{7} M T B+\beta_{8} S G R \\
& +\beta_{9} L e v+\beta_{10} \text { CEO_Tenure }+\beta_{11} C E O \_ \text {Age }+\beta_{12} C E O \_O w n e r \\
& +\beta_{13} \text { CEO_Dual }+ \text { year effects }
\end{aligned}
$$

The results of estimating the Tobit and OLS models are reported in Table 9. We find results similar in nature to those reported for CEO turnover in Model (3) in Table 5. In the Tobit model both EPS_Street and Exclusions are significantly and positively related to the bonuses paid to CEOs in the current year. Because the coefficient for Exclusions is positive and exclusions are, on average, income decreasing, the implication is that the greater the magnitude of expense exclusions, the lower the current year's bonus. The tenor of the results is unchanged when we estimate an OLS regression that includes CEO-firm fixed effects. The coefficient on EPS_Street is 0.543 while the coefficient on Exclusions is 0.741. An (untabulated) F-test fails to reject the hypothesis that the coefficients are equal ( $p$-value $=0.369)$. We also repeat this analysis for the three sub-periods in the spirit of Table 7. Untabulated results confirm that the above relations between street EPS and street exclusions hold in the first two sub-periods, but not in the C\&DI period. Therefore, we conclude from these analyses that boards also do not ignore street exclusions when designing bonus schemes for CEOs with the exception of the most recent period. ${ }^{18}$

[Insert Table 9 here]

\footnotetext{
18 This result is in contrast to Gaver and Gaver (1998). Their sample consists of 376 firms between 1970 and 1996 and they estimate firm-specific regressions which may explain differences in findings.
} 


\subsection{Additional robustness tests}

We conduct several additional tests to verify the robustness of our results to alternative specifications and control for potential omitted variables. For brevity, we do not tabulate the sensitivity tests but they are available upon request.

First, we examine a potential non-linear relation between street exclusions and turnover. This analysis is motivated by the view that small to moderate exclusions may be ignored or overlooked by boards. Specifically, we categorize Exclusions into quintiles and create indicator variables to represent each quintile. We then re-estimate our multinomial Model (3) of Table 5 using these indicator variables. As expected, forced turnover sensitivity is significant in two most negative exclusions group. Moreover, the sensitivity of turnover to exclusions monotonically declines in the quintile rank. These findings suggest that large negative exclusions lead boards to discipline CEOs faster. We also delete positive exclusions and re-estimate the model using a sample of only negative exclusions; the tenor of the results is similar.

CEOs compensation schemes may also influence CEO turnover decisions. We examine whether the relation between street exclusions and turnover is different between firms that emphasize relatively more short-term vs. long-term incentives. We compute a ratio of the sum of salary and bonus to total compensation for each CEO-firm observations. A larger (smaller) value of this ratio indicates that a CEO's compensation scheme is designed to provide more short-term (long-term) incentives. We divide the sample into two groups based on the median value of this ratio. The coefficients on EPS_Street and Exclusions remain negative for the long-term incentives sub-sample while only the coefficient on Exclusions is negative in the short-term incentives subsample (untabulated). A possible explanation for this finding is that "myopic" boards are likely to 
stress more current poor performance (captured in Exclusions) than persistent earnings (captured in EPS_Street).

We noted earlier that the dot.com crisis in the early 2000s and the great financial crisis of 2007-2008 may be exceptional years. Our first robustness test therefore is to exclude 2001, 2007 and 2008 from the sample and rerun our tests. After excluding these years, we find our results remain qualitatively unchanged.

One concern regarding our findings is that street exclusions may be influenced by manipulative and opportunistic communications from managers. If boards are aware of this possibility, they would have a strong reason to use GAAP earnings. If the manipulation of analysts' perceptions of street earnings is more common among managers who manipulate reported numbers, we need to verify that our results are not driven by these manipulative firms and managers. To do so, we add an indicator of adverse restatements, a proxy for manipulations, from the AuditAnalytics database to the models explored in Table 5. The results remain the same as we find that our results are similar for manipulating and non-manipulating firms.

It is possible that both poor GAAP earnings and the need to dismiss a CEO are driven by an omitted correlated variable. One plausible candidate for this underlying force is the strength of board monitoring. Weak monitoring can lead to both poor performance and eventually the need to oust the CEO. We therefore also examine whether the effect of exclusions on forced CEO turnover is affected by governance quality. Using the G-index data of Gombers et al. (2003), we add two indicator variables to our main multinomial model. ${ }^{19}$ Untabulated results reveal that both low and

\footnotetext{
19 We download governance index data from Andrew Metrick's webpage (http://faculty.som.yale.edu/andrewmetrick/data.html). This data is available for years 1993, 1995, 1998, 2000, 2002,
} 
high G-index indicators are insignificant to predict turnovers. Importantly, even with this limited sample Exclusions continues to be robust in explaining the likelihood of forced turnovers.

Another possible omitted variable is managerial talent. This is supported by the view that ability drives both performance and boards' assessment of the fit of the CEO with the firm. We therefore re-estimate our models after explicitly controlling for the effect of managerial ability. ${ }^{20}$ Untabulated results show that voluntary turnovers are marginally more likely for CEOs having a higher ability, but insignificant in predicting forced CEO turnovers. Thus, street exclusions contain information not captured by managerial ability scores. We also introduce into the model several other control variables, but our results remain similar. ${ }^{21}$

Our variables are deflated by the lagged share price. To the extent that markets anticipated price turnovers, this deflation may affect our inferences. Share prices tend to decrease prior to turnover and subsequently increase (see, for example, Huson et al., 2004). Hence, our deflated performance measures are likely larger for turnover firm-years and lower for other firm-years. While this works against finding a negative relation between the performance measures in question and subsequent CEO dismissal, we use an alternative deflator. Specifically, we use the average total assets per share and find that the results reported in Table 5 are qualitatively the same.

2004, and 2006. Larger G-index is associated with lower governance quality. Following Hazarika et al. (2012), our G-index indicator variables are defined as follows: LOW_G-INDEX (HIGH_G-INDEX) takes a value of one if Gindex is below 6 (above 12), otherwise zero.

20 We download managerial ability scores from Peter Demerjian's webpage (http://faculty.washington.edu/pdemerj/data.html) and included the variable MA_SCORE_2016 in our multinomial model. See, Demerjian et al. (2012) for details.

${ }^{21}$ These additional variables are: i) meeting analysts' earnings forecasts indicator variable (MEET); ii) indicator variable for street earnings losses (LOSS), because Ghosh and Wang (2018) show that losses are an important determinant of CEO turnovers, iii) and performance-adjusted absolute discretionary accruals (absDACC), because Hazarika et al. (2012) show that earnings management increase the likelihood of forced CEO turnover. 
We have followed prior literature in the classification of turnovers between forced and voluntary. We therefore conduct a placebo test to rule out the possibility that our findings are driven by the misidentification of relevant turnover events. In previous analyses we excluded CEO turnovers due to death (140 observations). As a placebo test, we include these cases and estimate a multinomial model in which the dependent variable identifies whether there was turnover (as originally defined), turnover due to death, or no CEO turnover in a given firm year. The results show that CEO's age is significantly positively associated with the probability of CEO's death. Importantly, our accounting performance measures do not predict CEO turnovers due to death.

In our analyses, we control for numerous firm and CEO characteristics. However, unobservable firm characteristics may still drive our results. Hence, to ensure that our results are not driven by correlated omitted variables, we re-estimate our models after controlling for firm fixed effects using two different approaches. First, we estimate a linear probability model using OLS and include firm fixed effects in our models. Second, we estimate a conditional logistic regression with firm fixed effects. Unlike the OLS fixed effects model, conditional logistic regression use only information from those firms that ousted their CEO at least once during the sample period. Results from both approaches are similar to our main results (untabulated). Specifically, that forced CEO turnovers, but not voluntary turnovers, are significantly related to street exclusions and street earnings. We therefore conclude that our results are not driven by some unobserved time-invariant firm characteristics.

\section{Summary}


Financial analysts often compute a measure of earnings, namely street earnings, that differs from reported earnings and use it in assessing a firm's performance and valuation. Street earnings typically exclude non-recurring expenses and losses from reported GAAP earnings. We investigate whether street exclusions that analysts disregard are also disregarded in boards' CEO retention decisions. If boards place great importance on the market's view of firm performance, street exclusions should be unrelated to retention decisions. However, we find that the likelihood and speed of CEO turnover are significantly related to street exclusions. Importantly, this result holds for forced turnovers but not for voluntary turnovers confirming the idea that exclusions are used by boards (although in combination of other elements of GAAP earnings). The result also holds before and after Regulation G (years 1993-3/2010), but not in the C\&DI period (4/2010-2016). Finally, in a similar vein, we show that street exclusions affect CEO bonus payouts. These findings suggest that in communicating with analysts, managers trade-off a higher exposure to board scrutiny of failure against maintaining a high stock price, which benefits their equity holdings. Our findings also suggest that managers who delay the reporting of write-offs also reduce the dismissal risk. However, this may increase the odds of punitive enforcement action by the SEC and shareholders (Hazarika et al., 2012).

As a final note, the lack of findings for the post-C\&DI period is intriguing. We encourage future research to study whether the role of GAAP earnings in CEO retention decisions have permanently disappeared. 


\section{References}

Alciatore, M., Easton, P. and Spear, N. 2000. Accounting for the impairment of long-lived assets: Evidence from the petroleum industry. Journal of Accounting and Economics, 29(2), 151172.

Baker, G., Gibbons, R., and Murphy, K.J., 1994. Subjective Performance Measures in Optimal Incentive Con- tracts. Quarterly Journal of Economics 109(4), 1125-1156.

Banker, R.D., and Datar, S.M., 1989. Sensitivity, precision, and linear aggregation of signals for performance evaluation. Journal of Accounting Research 27(1), 21-39.

Banker, R.D., Huang, R., and Natarajan, R., 2009. Incentive contracting and value relevance of earnings and cash flows. Journal of Accounting Research 47(3), 647-678.

Bartov, E., Givoly, D., and Hayn, C., 2002. The rewards to meeting or beating earnings expectations. Journal of Accounting and Economics 33(2), 173-204.

Bartov, E., Lindahl, F.W., and Ricks, W.E. 1998. Stock price behavior around announcements of write-offs. Review of Accounting Studies, 3(4), 327-346.

Bentley, J.W., Christensen, T.E., Gee, K.H., and Whipple, B.C. 2018. Disentangling Managers' and Analysts' Non-GAAP Reporting. Journal of Accounting Research 56(4), 1039-1081.

Bhagat, S., and Bolton, B. 2008. Corporate governance and firm performance. Journal of Corporate Finance 14(3), 257-273.

Bhattacharya, N., Black, E.L., Christensen, T.E., and Larson, C.R., 2003. Assessing the relative informativeness and permanence of pro forma earnings and GAAP operating earnings. Journal of Accounting and Economics 36(1-3), 285-319.

Bhattacharya, N., Black, E.L., Christensen, T.E., and Mergenthaler, R.D., 2007. Who trades on pro forma earnings information? The Accounting Review 82(3), 581-619.

Black, D. E., Black, E. L., Christensen, T. E., Gee, K. H. 2018. The use of non-GAAP performance metrics for compensation contracting and financial reporting. Working paper. Available at: http://dx.doi.org/10.2139/ssrn.2343140.

Black, D.E. and Christensen, T.E., 2018. Policy implications of research on non-GAAP reporting. Research in Accounting Regulation, 30(1), 1-7.

Bowen, R.M., Davis, A.K., and Matsumoto, D.A., 2005. Emphasis on pro forma versus GAAP earnings in quarterly press releases: Determinants, SEC intervention, and market reactions. The Accounting Review 80(4), 1011-1038. 
Bradshaw, M.T., 2003. A discussion of 'Assessing the relative informativeness and permanence of pro forma earnings and GAAP operating earnings'. Journal of Accounting and Economics 36(1), 321-335.

Bradshaw, M.T., and Sloan, R.G., 2002. GAAP versus the street: An empirical assessment of two alternative definitions of earnings. Journal of Accounting Research 40(1), 41-66.

Brickley, J.A., Coles, J.L., and Jarrell, G. 1997. Leadership structure: Separating the CEO and Chairman of the Board. Journal of Corporate Finance 3(3), 189-220.

Brickley, J.A., 2003. Empirical research on CEO turnover and firm-performance: a discussion. Journal of Accounting and Economics 36(1-3), 227-233.

Burgstahler, D., Jiambalvo, J., and Shevlin, T. 2002. Do stock prices fully reflect the implications of special items for future earnings? Journal of Accounting Research 40(3), 585-612.

Bushman, R., Dai, Z., and Wang, X., 2010. Risk and CEO turnover. Journal of Financial Economics 96(3), 381-398.

Bushman, R., Engel, E., and Smith, A. 2006. An Analysis of the Relation between the Stewardship and Valuation Roles of Earnings. Journal of Accounting Research, 44(1), 53-83.

Bushman, R.M., Lerman, A. and Zhang, X.F., 2016. The changing landscape of accrual accounting. Journal of Accounting Research, 54(1), .41-78.

Bushman, R., and Smith, A. 2001. Financial Accounting Information and Corporate Governance, Journal of Accounting and Economics, 32(1-3), 237-333.

Christensen, T.E., 2007. Discussion of "Letting the 'Tail Wag the Dog': The debate over GAAP versus street earnings revisited". Contemporary Accounting Research 24(3), 741-762.

Christensen, T.E., Merkley, K.J., Tucker, J.W., and Venkataraman, S., 2011. Do managers use earnings guidance to influence street earnings exclusions? Review of Accounting Studies 16(3), 501-527.

Curtis, A.B., McVay, S.E., and Whipple, B.C., 2013. The disclosure of non-GAAP earnings information in the presence of transitory gains. The Accounting Review 89(3), 933-958.

Dechow, P. M., Sloan, R., and Zha, J., 2014. Stock prices and earnings: a history of research. Annual Review of Financial Economics 6, 343-363.

DeFond, M.L., and Park, C.W., 1999. The effect of competition on CEO turnover. Journal of Accounting and Economics 27(1), 35-56. 
Demerjian, P., Lev, B., and McVay, S., 2012. Quantifying managerial ability: A new measure and validity tests. Management Science 58(7), 1229-1248.

Denis, D.J., and Denis, D.K., 1993. Performance Changes Following Top Management Dismissals. The Journal of Finance 50(4), 1029-1057.

Donelson, D.C., Jennings, R., and McInnis, J., 2011. Changes over time in the revenue-expense relation: Accounting or economics? The Accounting Review 86(3), 945-974.

Doyle, J.T., Jennings, J.N., and Soliman, M.T., 2013. Do managers define non-GAAP earnings to meet or beat analyst forecasts? Journal of Accounting and Economics 56(1), 40-56.

Doyle, J.T., Lundholm, R.J., and Soliman, M.T., 2003. The predictive value of expenses excluded from pro forma earnings. Review of Accounting Studies 8(2-3), 145-174.

Eisfeldt, A.L., and Kuhnen, C.M., 2013. CEO turnover in a competitive assignment framework. Journal of Financial Economics 109(2), 351-372.

Engel, E., Hayes, R.M., and Wang, X., 2003. CEO turnover and properties of accounting information. Journal of Accounting and Economics 36(1), 197-226.

Farrell, K.A., and Whidbee, D.A., 2003. Impact of firm performance expectations on CEO turnover and replacement decisions. Journal of Accounting and Economics 36(1), 165-196.

Fich, E.M., and Shivdasani, A., 2006. Are Busy Boards Effective Monitors? The Journal of Finance 61(2), 689-724.

Financial Accounting Standards Board (FASB), 2010. Statement of Financial Accounting Concepts No. 8, Norwalk, Connecticut.

Ford, J. 2016. The real cost of big tech's accounting games. The Financial Times, 8 May.

Frederickson, J.R., and Miller, J.S., 2004. The effects of pro forma earnings disclosures on analysts' and nonprofessional investors' equity valuation judgments. The Accounting Review 79(3), 667686.

Gaver, J.J. and Gaver, K.M., 1998. The relation between nonrecurring accounting transactions and CEO cash compensation. Accounting Review 73(2), 235-253.

Ghosh, A., and Wang, J., 2018. Accounting losses as a heuristic for managerial failure: Evidence from CEO turnovers. Journal of Financial and Quantitative Analysis forthcoming, https://doi.org/10.1017/S0022109018000728. 
Gjesdal, F., 1981. Accounting for stewardship. Journal of Accounting Research 19(1): 208-231.

Gombers, P., Ishii, J., and Metrick, A., 2003. Corporate governance and equity prices. The Quarterly Journal of Economics 118(1), 107-156.

Gow, I.D., Larcker, D.F., and Tayan, B., 2017. Retired or fired: how can investors tell if a CEO was pressured to leave? Rock Center for Corporate Governance.

Goyal, V.K., and Park, C.W., 2002. Board leadership structure and CEO turnover. Journal of Corporate Finance 8(1), .49-66.

Gu, Z., and Chen, T. 2004. Analysts' treatment of nonrecurring items in street earnings. Journal of Accounting and Economics 38, 129-170.

Guillamon-Saorin, E., Isidro, H., and Marques, A., 2017. Impression management and nonGAAP disclosure in earnings announcements. Journal of Business Finance \& Accounting 44(34), 448-479.

Hayes, R.M., and Schaefer, S., 2000. Implicit contracts and the explanatory power of top executive compensation for future performance. The RAND Journal of Economics 31(2), 273-293.

Hazarika, S., Karpoff, J.M., and Nahata, R., 2012. Internal corporate governance, CEO turnover, and earnings management. Journal of Financial Economics 104(1), 44-69.

Heflin, F., and Hsu. C., 2008. The impact of the SEC's regulation of non-GAAP disclosures. Journal of Accounting and Economics 46(2-3), 349-365.

Hirschey, M., and Richardson, V.J. 2002. Information content of accounting goodwill numbers. Journal of Accounting and Public Policy, 21(3), 173-191.

Holmstrom, B., and Milgrom, P.R., 1991. Multitask principal-agent analyses: incentive contracts, asset ownership and job design. Journal of Law, Economics and Organization 7, 524552.

Hosmer, D.W., and Jr., Lemeshow, S. 1999. Applied Survival Analysis. New York, NY, Wiley.

Huson, M.R., Malatesta, P.H., and Parrino, R., 2004. Managerial succession and firm performance. Journal of Financial Economics 74(2), 237-275.

Huson, M.R., Parrino, R., and Starks, L.T., 2001. Internal monitoring mechanisms and CEO turnover: a long term perspective. The Journal of Finance 56(6), 2265-2297 
Isidro, H., and Marques, A., 2013. The effects of compensation and board quality on non-GAAP reporting decisions. The International Journal of Accounting 48(3), 289-317.

Jarva, H., 2009. Do firms manage fair value estimates? An examination of SFAS 142 goodwill impairments. Journal of Business Finance and Accounting 36(9-10): 1059-1086.

Jenter, D., and Kanaan, F., 2015. CEO turnover and relative performance evaluation. The Journal of Finance 70(5), 2155-2184.

Kolev, K., C. Marquardt, C., and McVay, S. 2008. SEC scrutiny and the evolution of nonGAAP reporting. The Accounting Review 83(1): 157-184.

Kothari, S.P., Ramanna, K., and Skinner, D.J. 2010. Implications for GAAP from an analysis of positive research in accounting. Journal of Accounting and Economics 50(2-3), 246-286.

Leone, A.J., and Liu, M., 2010. Accounting irregularities and executive turnover in foundermanaged firms. The Accounting Review 85(1), 287-314.

Lev, B., 2018. The deteriorating usefulness of financial report information and how to reverse it. Accounting and Business Research, 48(5), pp.465-493.

Li, K.K, and Sloan, R.G., 2017. Has goodwill accounting gone bad? Review of Accounting Studies 22(2): 964-1003.

Li, C., Sun, L., and Ettredge, M., 2010. Financial executive qualifications, financial executive turnover, and adverse SOX 404 opinions. Journal of Accounting and Economics 50(1), 93-110.

Lim, T. 2001. Rationality and analysts' forecast bias. The Journal of Finance 56(1), 369-385.

Marques, A., 2006. SEC interventions and the frequency and usefulness of non-GAAP financial measures. Review of Accounting Studies 11(4), 549-574.

Murphy, K.J., and Zimmerman, J.L., 1993. Financial performance surrounding CEO turnover. Journal of Accounting and Economics 16(1-3), 273-315.

Parrino, R., 1997. CEO turnover and outside succession a cross-sectional analysis. Journal of Financial Economics 46(2), 165-197.

Parrino, R., Sias, R.W., and Starks, L.T., 2003. Voting with their feet: Institutional ownership changes around forced CEO turnover. Journal of Financial Economics 68(1), 3-46.

Paul, J. M. 1992. On the Efficiency of Stock-based Compensation. The Review of Financial Studies, 5(3), 471-502. 
Pourciau, S., 1993. Earnings management and nonroutine executive changes. Journal of Accounting and Economics 16(1-3), 317-336.

Potepa, J., 2014. The treatment of special items in determining CEO cash compensation.Working paper, available on https://ssrn.com/abstract=2426669.

Vuong, Q.H., 1987. Likelihood ratio tests for model selection and non-nested hypotheses. Econometrica 57(2), 307-333.

Wagenhofer, A. 2009. Global Accounting Standards: Reality and Ambitions, Accounting Research Journal, 22(1), 68-80.

Weisbach, M.S., 1988. Outside directors and CEO turnover. Journal of Financial Economics 20, 431-460. 


\section{Appendix}

\begin{tabular}{|c|c|}
\hline Variable name & Measurement and source of data \\
\hline \multicolumn{2}{|l|}{ Dependent variables } \\
\hline$\overline{C E O \_T O}$ & $\begin{array}{l}\text { Indicator variable: Chief executive officer (CEO) turnover is } \\
\text { identified based on whether the same individual holds the CEO title } \\
\text { during the current and subsequent year, taking a value of } 1 \text { if the CEO } \\
\text { has changed and } 0 \text { otherwise. }\end{array}$ \\
\hline logTenure & $\begin{array}{l}\text { Log of the number of years that the CEO is in office (i.e., the CEO's } \\
\text { survival time). }\end{array}$ \\
\hline $\log (1+$ Bonus $)$ & Log of one plus the CEO's cash bonus. \\
\hline \multicolumn{2}{|l|}{ Main variables } \\
\hline EPS_GAAP & $\begin{array}{l}\text { Earnings per share (EPS), excluding extraordinary items from } \\
\text { Compustat, scaled by the lagged stock price from Compustat. }\end{array}$ \\
\hline EPS_Street & $\begin{array}{l}\text { EPS reported by I/B/E/S scaled by the lagged stock price from } \\
\text { Compustat. }\end{array}$ \\
\hline Exclusions & EPS_GAAP-EPS_Street \\
\hline \multicolumn{2}{|l|}{ Control variables } \\
\hline For_Rev & $\begin{array}{l}\text { Analyst forecast revision: Mean consensus EPS estimate from the las } \\
\text { month of the fiscal year reported by I/B/E/S minus the same estimate } \\
\text { made nine months earlier scaled by the lagged stock price from } \\
\text { Compustat. }\end{array}$ \\
\hline Ret_Idio & $\begin{array}{l}\text { Idiosyncratic return: The residual value from the annual cross- } \\
\text { sectional (using the two-digit SIC code classification) regressions that } \\
\text { use an intercept to predict the firm's annual returns (calculated from } \\
\text { the CRSP monthly return files). }\end{array}$ \\
\hline Ret_Peer & $\begin{array}{l}\text { Industry return: The fitted value from the annual cross-sectional } \\
\text { (using the two-digit SIC code classification) regressions that use an } \\
\text { intercept to predict the firm's annual returns (calculated from the } \\
\text { CRSP monthly return files). }\end{array}$ \\
\hline Std_Ret & $\begin{array}{l}\text { Standard deviation of the firm's stock return over the } 12 \text { months } \\
\text { ending at the fiscal year-end. }\end{array}$ \\
\hline MTB & $\begin{array}{l}\text { The market-to-book ratio is the sum of total liabilities plus the market } \\
\text { value of equity deflated by the firm's total assets. }\end{array}$ \\
\hline $\log M V E$ & The natural logarithm of the market value of equity. \\
\hline$S G R$ & $\begin{array}{l}\text { Sales growth is defined as change in sales divided by beginning of } \\
\text { period sales. }\end{array}$ \\
\hline$L E V$ & $\begin{array}{l}\text { The book leverage ratio is defined as long-term debt plus the current } \\
\text { portion of long-term debt deflated by total assets. }\end{array}$ \\
\hline CEO_Age & CEO's age measured in years. \\
\hline CEO_Owne & CEO's shareholding in the firm. \\
\hline
\end{tabular}


Appendix (continued)

\begin{tabular}{ll}
\hline Variable name & Measurement and source of data \\
\hline CEO_Dual & $\begin{array}{l}\text { Indicator variable: } 1 \text { if the CEO is also the chairman and } 0 \\
\text { otherwise. } \\
\text { Cost of goods sold divided by the beginning-of-period market value } \\
\text { of equity. }\end{array}$ \\
Selling, general and administrative expenses divided by the \\
beginning-of-period market value of equity. \\
Depreciation and amortization divided by the beginning-of-period \\
market value of equity. \\
Income taxes divided by the beginning-of-period market value of \\
equity. \\
Special items divided by the beginning-of-period market value of \\
equity. \\
The difference between expenses (sales minus income before \\
extraordinary items) and other income statement components \\
(COGS, SGA,Depr,Tax, and $S I)$.
\end{tabular}




\section{Figure 1 \\ GAAP earnings versus street earnings}

Figure 1A: Mean values over time

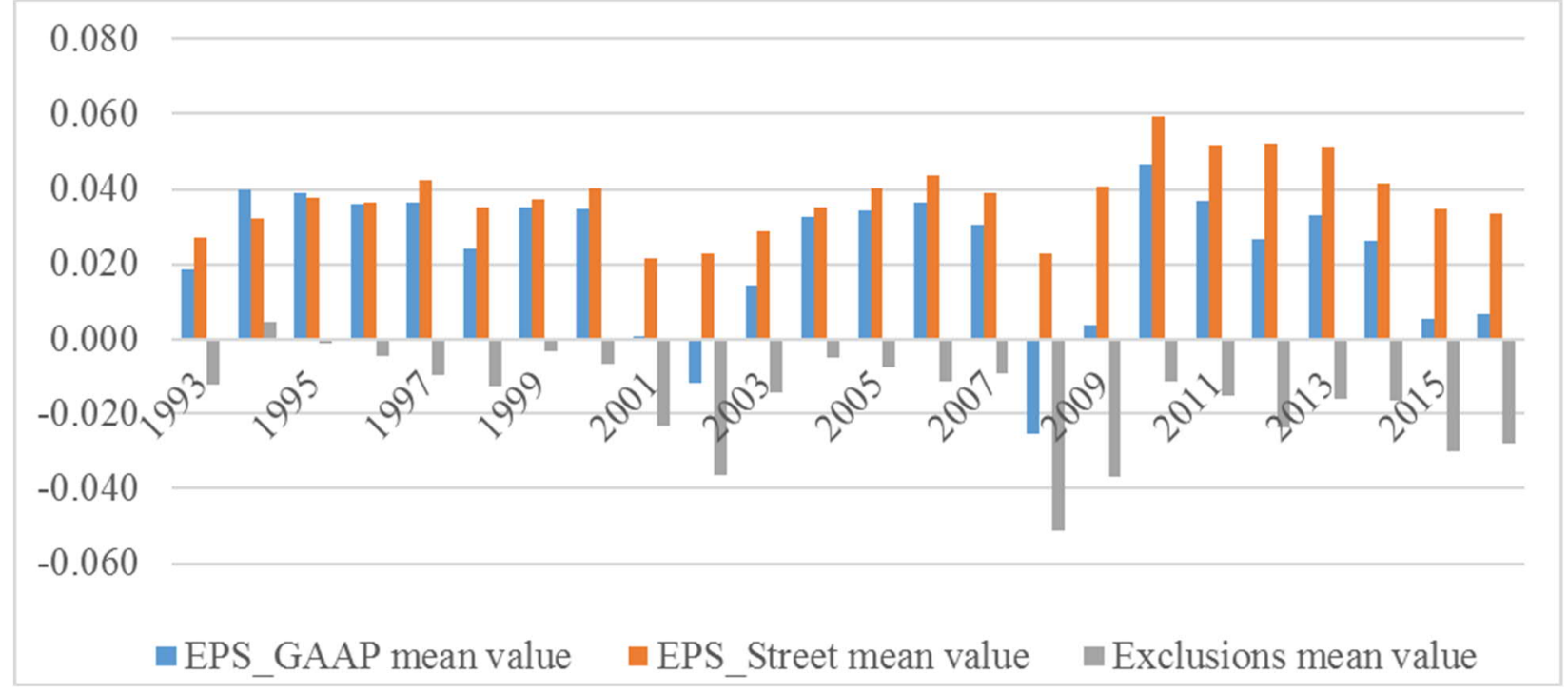

Figure 1B: Standard deviation over time

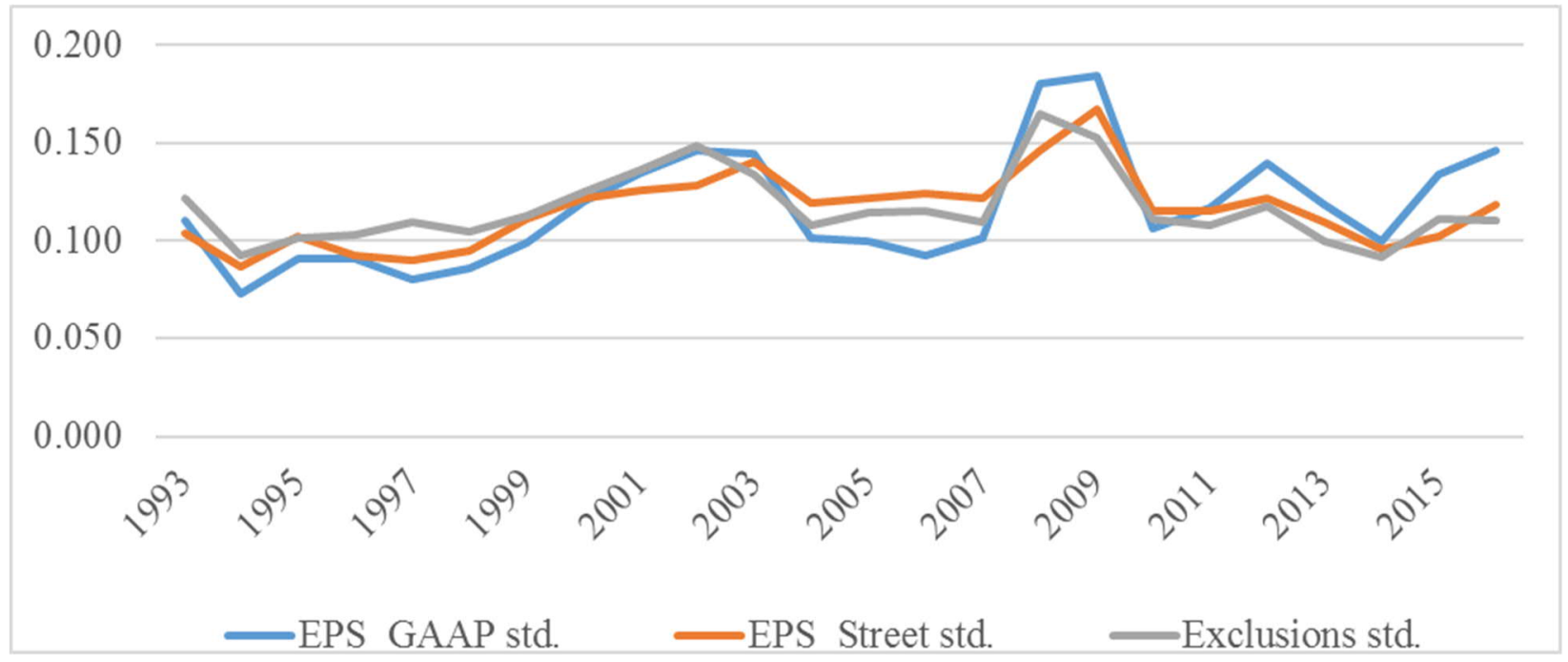

Figure 1A (1B) Plots the mean (standard deviation) values of EPS_GAAP, EPS_Street, and Exclusions from 1993 to 2016. EPS_GAAP is earnings per share, including extraordinary items from Compustat, scaled by the lagged stock price from Compustat. EPS_Street is earnings per share from I/B/E/S scaled by the lagged stock price from Compustat. Exclusions are EPS_GAAP minus EPS_Street. 
Table 1

Frequencies of CEO turnovers.

\begin{tabular}{|c|c|c|c|c|}
\hline Year & $\begin{array}{c}\text { Number of } \\
\text { observations }\end{array}$ & $\begin{array}{l}\text { Number of } \\
\text { turnovers }\end{array}$ & Forced turnovers & $\begin{array}{c}\text { Forced as a } \% \text { of } \\
\text { total turnovers }\end{array}$ \\
\hline 1993 & 667 & 71 & 13 & $18.3 \%$ \\
\hline 1994 & 918 & 93 & 17 & $18.3 \%$ \\
\hline 1995 & 955 & 85 & 35 & $41.2 \%$ \\
\hline 1996 & 992 & 84 & 27 & $32.1 \%$ \\
\hline 1997 & 1,021 & 89 & 26 & $29.2 \%$ \\
\hline 1998 & 1,073 & 110 & 21 & $19.1 \%$ \\
\hline 1999 & 1,088 & 115 & 31 & $27.0 \%$ \\
\hline 2000 & 1,081 & 95 & 31 & $32.6 \%$ \\
\hline 2001 & 1,043 & 87 & 18 & $20.7 \%$ \\
\hline 2002 & 1,075 & 97 & 31 & $32.0 \%$ \\
\hline 2003 & 1,106 & 91 & 21 & $23.1 \%$ \\
\hline 2004 & 1,126 & 132 & 32 & $24.2 \%$ \\
\hline 2005 & 1,080 & 102 & 32 & $31.4 \%$ \\
\hline 2006 & 1,051 & 93 & 27 & $29.0 \%$ \\
\hline 2007 & 1,182 & 133 & 46 & $34.6 \%$ \\
\hline 2008 & 1,322 & 108 & 29 & $26.9 \%$ \\
\hline 2009 & 1,323 & 85 & 26 & $30.6 \%$ \\
\hline 2010 & 1,305 & 140 & 40 & $28.6 \%$ \\
\hline 2011 & 1,262 & 120 & 45 & $37.5 \%$ \\
\hline 2012 & 1,237 & 131 & 28 & $21.4 \%$ \\
\hline 2013 & 1,211 & 144 & 32 & $22.2 \%$ \\
\hline 2014 & 1,199 & 171 & 46 & $26.9 \%$ \\
\hline 2015 & 1,146 & 129 & 30 & $23.3 \%$ \\
\hline 2016 & 1,108 & 130 & 32 & $24.6 \%$ \\
\hline Total & 26,571 & 2,635 & 716 & $27.2 \%$ \\
\hline
\end{tabular}

This table reports the total number of firm-year observations and cases of CEO turnover and forced CEO turnovers from 1993-2016. The data exclude the CEO's first year in office, CEO turnover unrelated to the board's decision to dismiss the CEO (death, poor health, interim appointments, mergers, spinoffs, and retirements because of old age), and firms in the financial and utility sectors (SIC codes between 6000-6999 and 4900-4999). 
Table 2

GAAP earnings vs. street earnings: mean values and standard deviations.

\begin{tabular}{ccccccc}
\hline & EPS_GAAP & EPS_GAAP & EPS_Street & EPS_Street & Exclusions & $\begin{array}{c}\text { Exclusions } \\
\text { Year }\end{array}$ \\
Mean & Std. & Mean & Std. & Mean & Std. \\
\hline 1993 & 0.019 & 0.111 & 0.027 & 0.104 & -0.012 & 0.122 \\
1994 & 0.040 & 0.073 & 0.032 & 0.087 & 0.005 & 0.093 \\
1995 & 0.039 & 0.091 & 0.038 & 0.103 & -0.001 & 0.101 \\
1996 & 0.036 & 0.091 & 0.037 & 0.092 & -0.005 & 0.103 \\
1997 & 0.036 & 0.080 & 0.042 & 0.090 & -0.010 & 0.110 \\
1998 & 0.024 & 0.086 & 0.035 & 0.095 & -0.013 & 0.105 \\
1999 & 0.035 & 0.099 & 0.037 & 0.111 & -0.003 & 0.113 \\
2000 & 0.035 & 0.120 & 0.040 & 0.122 & -0.007 & 0.125 \\
2001 & 0.001 & 0.135 & 0.021 & 0.126 & -0.023 & 0.136 \\
2002 & -0.012 & 0.146 & 0.023 & 0.129 & -0.037 & 0.149 \\
2003 & 0.015 & 0.144 & 0.029 & 0.140 & -0.015 & 0.134 \\
2004 & 0.033 & 0.102 & 0.035 & 0.120 & -0.005 & 0.108 \\
2005 & 0.034 & 0.100 & 0.040 & 0.122 & -0.008 & 0.114 \\
2006 & 0.036 & 0.093 & 0.044 & 0.124 & -0.011 & 0.116 \\
2007 & 0.031 & 0.102 & 0.039 & 0.122 & -0.009 & 0.110 \\
2008 & -0.026 & 0.181 & 0.023 & 0.146 & -0.051 & 0.165 \\
2009 & 0.004 & 0.184 & 0.041 & 0.167 & -0.037 & 0.153 \\
2010 & 0.047 & 0.106 & 0.059 & 0.115 & -0.012 & 0.111 \\
2011 & 0.037 & 0.117 & 0.052 & 0.115 & -0.015 & 0.108 \\
2012 & 0.027 & 0.140 & 0.052 & 0.122 & -0.024 & 0.118 \\
2013 & 0.033 & 0.119 & 0.051 & 0.110 & -0.016 & 0.100 \\
2014 & 0.026 & 0.100 & 0.042 & 0.096 & -0.017 & 0.092 \\
2015 & 0.005 & 0.134 & 0.035 & 0.102 & -0.030 & 0.111 \\
2016 & 0.007 & 0.146 & 0.034 & 0.118 & -0.028 & 0.110 \\
Total & 0.023 & 0.123 & 0.038 & 0.119 & -0.017 & 0.120 \\
\hline
\end{tabular}

This table shows the mean and standard deviation values for GAAP_EPS, Street_EPS, and Exclusions from 1993 to 2015. The data exclude the CEO's first year in office, CEO turnover unrelated to the board's decision to dismiss the CEO (death, poor health, interim appointments, mergers, spinoffs, and retirements because of old age), and firms in the financial and utility sectors (SIC codes between 6000-6999 and 4900-4999). EPS_GAAP is earnings per share, including extraordinary items from Compustat, scaled by the lagged stock price from Compustat. EPS_Street is earnings per share from I/B/E/S scaled by the lagged stock price from Compustat. Exclusions are EPS_GAAP minus EPS_Street. 
Table 3

Summary statistics and univariate comparisons.

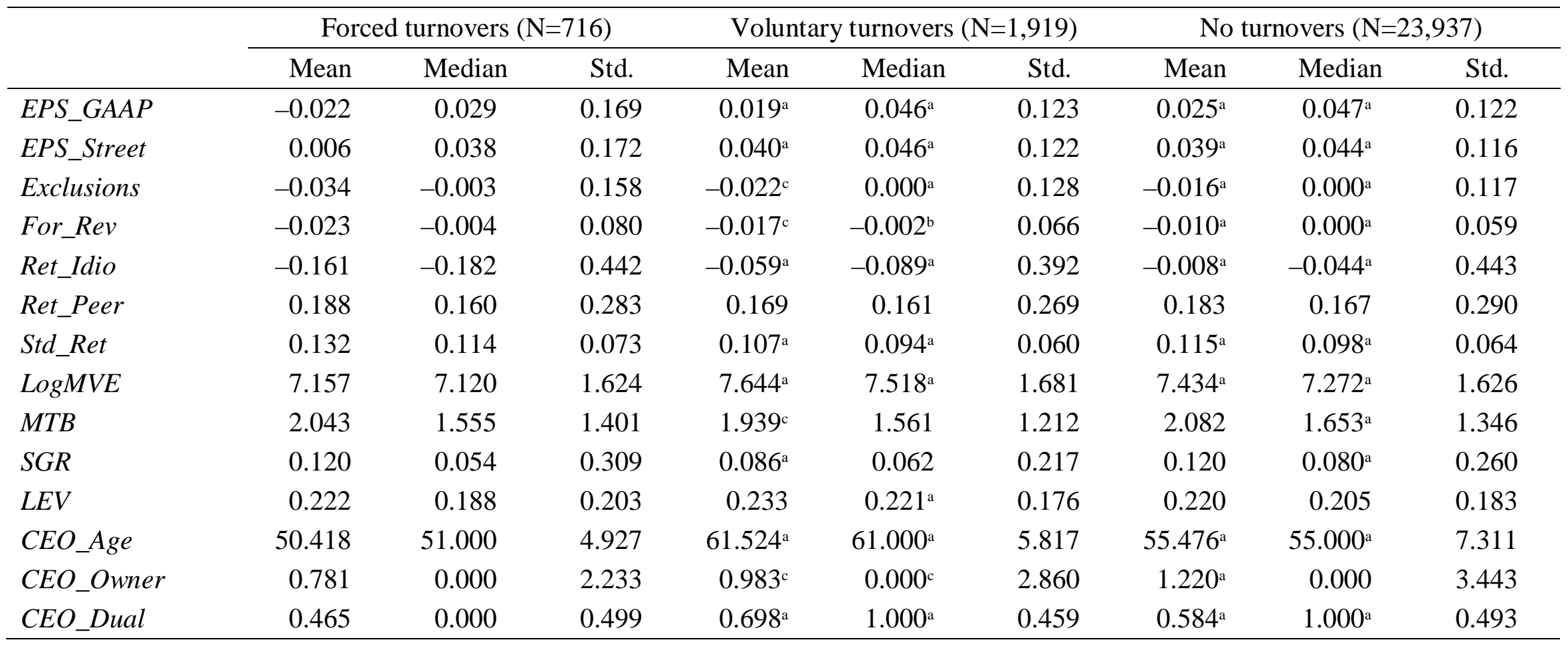

This table reports the means, medians, and standard deviations for selected variables by three CEO turnover groups from 1993 to 2016 : i) The forced CEO turnover sample consists of 716 firm-years; ii) The voluntary CEO turnover consists of 1,919 firm-years; and iii) No turnovers sample consists of 23,937 firm-years. The data exclude the CEO's first year in office, CEO turnover unrelated to the board's decision to dismiss the CEO (death, poor health, interim appointments, mergers, spinoffs, and retirements because of old age), and firms in the financial and utility sectors (SIC codes between 6000-6999 and 4900-4999). EPS_GAAP is GAAP earnings per share scaled by the lagged price. EPS_Street is street earnings per share scaled by the lagged price. Exclusions are items included in GAAP earnings but excluded from street earnings. For_Rev is the analysts' forecast revisions during the fiscal year. Ret_Idio is the idiosyncratic return. Ret_Peer is the industry return. Std_Ret is return volatility. $\log M V E$ is the logarithm of the market value of equity. MTB is the market-to-book ratio. SGR is sales growth. $L E V$ is leverage. CEO_Age is the CEO's age. CEO_Owner is the CEO's percentage of total shares owned. CEO_Dual is the CEO-chairman duality indicator. Full variable definitions are provided in the Appendix. The mean and median differences between the forced turnover vs. voluntary turnover and forced turnover and no turnover samples are tested using a $t$-test and Wilcoxon $z$-test, respectively. The superscripts ${ }^{\mathrm{a}},{ }^{\mathrm{b}}$, and ${ }^{\mathrm{c}}$ denote significance at the $1 \%, 5 \%$, and $10 \%$ levels, respectively, for a two-tailed test. 


\section{Table 4}

Correlations.

\begin{tabular}{|c|c|c|c|c|c|c|c|c|c|c|c|c|c|c|}
\hline Variable & (1) & (2) & (3) & $(4)$ & $(5)$ & (6) & (7) & $(8)$ & $(9)$ & (10) & $(11)$ & (12) & (13) & (14) \\
\hline (1) EPS_GAAP & & .642 & .495 & .406 & .278 & .120 & -.275 & .180 & .026 & .129 & .005 & .091 & .013 & .071 \\
\hline (2) EPS_Street & .593 & & -.172 & .327 & .190 & .071 & -.207 & .163 & -.101 & .026 & .088 & .077 & .143 & .023 \\
\hline (3) Exclusions & .468 & -.364 & & .193 & .154 & .073 & -.122 & .055 & .188 & .182 & -.108 & .033 & -.135 & .064 \\
\hline (4) For_Rev & .433 & .399 & .092 & & .403 & .144 & -.109 & .209 & .289 & .342 & -.095 & -.023 & .044 & -.006 \\
\hline (5) Ret_Idio & .173 & .129 & .070 & .233 & & -.103 & -.093 & .170 & .286 & .176 & -.039 & .002 & .019 & -.002 \\
\hline (6) Ret_Peer & .077 & .040 & .048 & .072 & -.061 & & -.028 & .077 & .183 & .057 & -.066 & -.008 & -.025 & .024 \\
\hline (7) Std_Ret & -.356 & -.249 & -.118 & -.165 & .034 & .049 & & -.435 & -.136 & .033 & -.071 & -.147 & -.035 & -.092 \\
\hline (8) LogMVE & .252 & .202 & .067 & .193 & .116 & .078 & -.390 & & .343 & .066 & .117 & .097 & -.031 & .138 \\
\hline (9) $M T B$ & .071 & -.037 & .112 & .123 & .286 & .170 & .032 & .261 & & .293 & -.297 & -.071 & -.031 & -.019 \\
\hline (10) SGR & .157 & .082 & .077 & .195 & .165 & .069 & .074 & .041 & .274 & & -.093 & -.077 & -.107 & -.001 \\
\hline (11) LEV & -.143 & -.040 & -.118 & -.092 & -.047 & -.067 & -.005 & .066 & -.224 & -.050 & & .065 & -.060 & .081 \\
\hline (12) CEO_Age & .054 & .051 & .002 & .001 & -.018 & -.014 & -.146 & .090 & -.098 & -.091 & .051 & & .076 & .265 \\
\hline (13) CEO_Owner & -.007 & -.005 & -.005 & .007 & .008 & -.042 & .004 & -.097 & .000 & -.029 & -.093 & .120 & & -.080 \\
\hline (14) CEO_Dual & .054 & .042 & .012 & -.004 & -.014 & .023 & -.080 & .143 & -.021 & -.010 & .057 & .263 & .079 & \\
\hline
\end{tabular}

This table reports Pearson correlations below the diagonal and Spearman correlations above the diagonal. Correlations for which the absolute value is greater than 0.014 are significant at the 0.01 level. All variables are as defined in Table 3 and the Appendix 
Table 5

Multinomial logistic regression relating forced and voluntary CEO turnover to performance measures.

\begin{tabular}{|c|c|c|c|c|c|c|}
\hline \multirow[b]{2}{*}{ Variable } & \multicolumn{2}{|c|}{ Model (1) } & \multicolumn{2}{|c|}{ Model (2) } & \multicolumn{2}{|c|}{ Model (3) } \\
\hline & Forced & Voluntary & Forced & Voluntary & Forced & Voluntary \\
\hline$E P S \_G A A P$ & $-1.108(0.000)$ & $-0.363(0.133)$ & & & & \\
\hline EPS_Street & & & $-0.679(0.034)$ & $0.061(0.792)$ & $-1.164(0.001)$ & $-0.089(0.745)$ \\
\hline Exclusions & & & & & $-1.019(0.001)$ & $-0.239(0.313)$ \\
\hline For_Rev & $-0.511(0.378)$ & $-1.216(0.005)$ & $-0.653(0.282)$ & $-1.484(0.000)$ & $-0.383(0.525)$ & $-1.360(0.002)$ \\
\hline Ret_Idio & $-0.705(0.000)$ & $-0.254(0.000)$ & $-0.730(0.000)$ & $-0.266(0.000)$ & $-0.706(0.000)$ & $-0.261(0.000)$ \\
\hline Ret_Peer & $0.190(0.350)$ & $-0.123(0.361)$ & $0.172(0.397)$ & $-0.132(0.328)$ & $0.194(0.341)$ & $-0.127(0.344)$ \\
\hline Std_Ret & $2.616(0.000)$ & $1.203(0.031)$ & $3.060(0.000)$ & $1.455(0.007)$ & $2.585(0.000)$ & $1.350(0.015)$ \\
\hline LogMVE & $0.037(0.223)$ & $0.083(0.000)$ & $0.029(0.333)$ & $0.079(0.000)$ & $0.039(0.202)$ & $0.080(0.000)$ \\
\hline$M T B$ & $-0.039(0.282)$ & $-0.028(0.262)$ & $-0.040(0.265)$ & $-0.025(0.329)$ & $-0.040(0.273)$ & $-0.025(0.320)$ \\
\hline$S G R$ & $-0.080(0.606)$ & $-0.275(0.024)$ & $-0.125(0.419)$ & $-0.299(0.014)$ & $-0.083(0.592)$ & $-0.290(0.017)$ \\
\hline$L E V$ & $0.127(0.572)$ & $0.104(0.497)$ & $0.244(0.269)$ & $0.138(0.365)$ & $0.127(0.571)$ & $0.118(0.442)$ \\
\hline CEO_Age & $-0.096(0.000)$ & $0.121(0.000)$ & $-0.097(0.000)$ & $0.121(0.000)$ & $-0.096(0.000)$ & $0.121(0.000)$ \\
\hline CEO_Owner & $-0.067(0.001)$ & $-0.090(0.000)$ & $-0.068(0.000)$ & $-0.090(0.000)$ & $-0.067(0.001)$ & $-0.090(0.000)$ \\
\hline CEO_Dual & $-0.050(0.551)$ & $0.051(0.382)$ & $-0.047(0.574)$ & $0.051(0.382)$ & $-0.048(0.571)$ & $0.051(0.383)$ \\
\hline Year indicators & Yes & Yes & Yes & Yes & Yes & Yes \\
\hline Industry indicators & Yes & Yes & Yes & Yes & Yes & Yes \\
\hline Pseudo- $\mathrm{R}^{2}$ & \multicolumn{2}{|c|}{$10.82 \%$} & \multicolumn{2}{|c|}{$10.77 \%$} & \multicolumn{2}{|c|}{$10.83 \%$} \\
\hline Number of firm-years & \multicolumn{2}{|c|}{26,571} & \multicolumn{2}{|c|}{26,571} & \multicolumn{2}{|c|}{26,571} \\
\hline
\end{tabular}

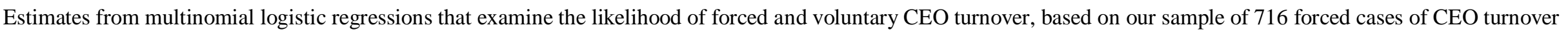

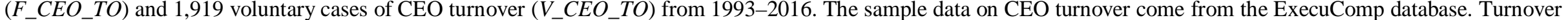

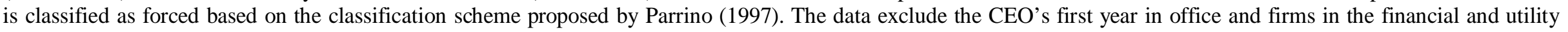

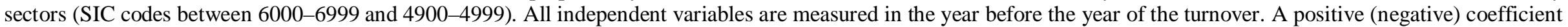

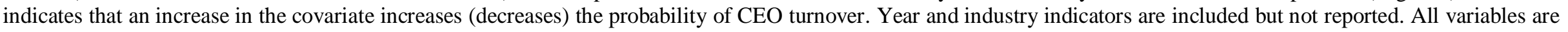
as defined in Table 3 and the Appendix. 


\section{Table 6}

Cox proportional hazard model relating forced CEO turnover to performance measures.

\begin{tabular}{|c|c|c|c|}
\hline Variable & Model (1) & Model (2) & Model (3) \\
\hline EPS_GAAP & $-0.943 \quad(0.000)$ & & \\
\hline EPS_Street & & $0.082 \quad(0.663)$ & $-0.517 \quad(0.010)$ \\
\hline Exclusions & & & $-1.092 \quad(0.000)$ \\
\hline For_Rev & $-1.144 \quad(0.000)$ & $-1.973(0.000)$ & $-1.409 \quad(0.000)$ \\
\hline Ret_Idio & $-0.146 \quad(0.001)$ & $-0.175 \quad(0.000)$ & $-0.152 \quad(0.000)$ \\
\hline Ret_Peer & $0.077 \quad(0.417)$ & $0.059 \quad(0.536)$ & $0.068 \quad(0.474)$ \\
\hline Std_Ret & $1.133(0.001)$ & $1.767 \quad(0.000)$ & $1.308 \quad(0.000)$ \\
\hline $\log M V E$ & $0.076 \quad(0.000)$ & $0.068 \quad(0.000)$ & $0.075 \quad(0.000)$ \\
\hline$M T B$ & $-0.063 \quad(0.000)$ & $-0.056 \quad(0.001)$ & $-0.057 \quad(0.000)$ \\
\hline$S G R$ & $-0.254 \quad(0.001)$ & $-0.304 \quad(0.000)$ & $-0.268 \quad(0.000)$ \\
\hline$L E V$ & $0.392(0.000)$ & $0.471 \quad(0.000)$ & $0.381 \quad(0.000)$ \\
\hline CEO_Age & $-0.143 \quad(0.000)$ & $-0.139 \quad(0.000)$ & $-0.139 \quad(0.000)$ \\
\hline CEO_Owner & $-0.127 \quad(0.000)$ & $-0.128 \quad(0.000)$ & $-0.128 \quad(0.000)$ \\
\hline CEO_Dual & $-0.235 \quad(0.000)$ & $-0.232(0.000)$ & $-0.228 \quad(0.000)$ \\
\hline Year indicators & Yes & Yes & Yes \\
\hline Industry indicators & Yes & Yes & Yes \\
\hline Number of events & 3,008 & 3,008 & 3,008 \\
\hline $\begin{array}{l}\text { Number of censored } \\
\text { data }\end{array}$ & 23,563 & 23,563 & 23,563 \\
\hline
\end{tabular}

The dependent variable is the number of years that the CEO is in office (logTenure). A positive (negative) Cox proportional hazards model coefficient indicates a shorter (longer) expected time as CEO. The sample consists of 26,571 firm-year observations, 716 of which are forced CEO turnovers (3,008 event firm-years), from 1993 to 2016. Data are right censored for CEOs in office at December 31, 2016, who have not yet left their position. Also voluntary turnovers are censored. The data exclude the CEO's first year in office, CEO turnover unrelated to the board's decision to dismiss the CEO (death, poor health, interim appointments, mergers, spinoffs, and retirements because of old age), and firms in the financial and utility sectors (SIC codes between 6000-6999 and 4900-4999). Year and industry indicators are included but not reported. Industries are classified using the Fama-French 48-industry classification. $p$ values appear in parentheses. All variables are as defined in Table 3 and the Appendix. 


\section{Table 7}

How regulation changes affected CEO turnover-performance sensitivity?

\begin{tabular}{|c|c|c|c|c|c|c|c|c|}
\hline \multicolumn{9}{|c|}{ Panel A: Pre-Regulation G period (1993-3/2003) vs. post-regulation G period (4/2003-2016) } \\
\hline \multirow{3}{*}{$\frac{\text { Variable }}{\text { EPS_Street }}$} & \multicolumn{4}{|c|}{ Pre-Regulation G period } & \multicolumn{4}{|c|}{ Post-Regulation G period } \\
\hline & \multicolumn{2}{|c|}{ Forced } & \multicolumn{2}{|c|}{ Voluntary } & \multicolumn{2}{|c|}{ Forced } & \multicolumn{2}{|c|}{ Voluntary } \\
\hline & -0.979 & $(0.097)$ & -0.114 & $(0.827)$ & -1.229 & $(0.003)$ & 0.091 & $(0.782)$ \\
\hline Exclusions & -1.377 & $(0.005)$ & -0.141 & $(0.748)$ & -0.734 & $(0.056)$ & -0.209 & $(0.464)$ \\
\hline For_Rev & -1.314 & $(0.175)$ & -1.520 & $(0.046)$ & 0.421 & $(0.580)$ & -1.397 & $(0.011)$ \\
\hline Ret_Idio & -0.621 & $(0.000)$ & -0.300 & $(0.006)$ & -0.789 & $(0.000)$ & -0.252 & $(0.006)$ \\
\hline Ret_Peer & 0.447 & $(0.106)$ & -0.070 & (0.709) & 0.004 & $(0.990)$ & -0.163 & $(0.424)$ \\
\hline Std_Ret & 3.917 & $(0.001)$ & 0.833 & $(0.352)$ & 2.063 & $(0.051)$ & 1.950 & $(0.008)$ \\
\hline LogMVE & 0.123 & $(0.021)$ & 0.127 & $(0.000)$ & -0.006 & $(0.878)$ & 0.060 & $(0.013)$ \\
\hline$M T B$ & -0.084 & $(0.153)$ & 0.013 & $(0.745)$ & -0.018 & $(0.696)$ & -0.046 & $(0.160)$ \\
\hline$S G R$ & 0.099 & $(0.628)$ & -0.182 & $(0.321)$ & -0.295 & $(0.218)$ & -0.377 & $(0.023)$ \\
\hline$L E V$ & 0.578 & $(0.134)$ & 0.559 & $(0.047)$ & -0.021 & $(0.942)$ & -0.112 & $(0.552)$ \\
\hline CEO_Age & -0.074 & $(0.000)$ & 0.124 & $(0.000)$ & -0.115 & $(0.000)$ & 0.121 & $(0.000)$ \\
\hline CEO_Owner & -0.294 & $(0.308)$ & -0.028 & $(0.640)$ & -0.069 & $(0.000)$ & -0.097 & $(0.000)$ \\
\hline CEO_Dual & -0.078 & $(0.582)$ & -0.001 & $(0.991)$ & -0.005 & $(0.965)$ & 0.097 & $(0.160)$ \\
\hline Year indicators & \multicolumn{4}{|c|}{ Yes } & \multicolumn{4}{|c|}{ Yes } \\
\hline Industry indicators & \multicolumn{4}{|c|}{ Yes } & \multicolumn{4}{|c|}{ Yes } \\
\hline Pseudo- $\mathrm{R}^{2}$ & \multicolumn{4}{|c|}{$12.22 \%$} & \multicolumn{4}{|c|}{$11.00 \%$} \\
\hline Cases of turnover & \multicolumn{2}{|c|}{250} & \multicolumn{2}{|c|}{679} & \multicolumn{2}{|c|}{466} & \multicolumn{2}{|c|}{1,240} \\
\hline Firm-years & & & & & & & & \\
\hline
\end{tabular}




\begin{tabular}{|c|c|c|c|c|c|c|c|c|}
\hline \multicolumn{9}{|c|}{ Panel B: Further analysis of the post-regulation $\mathrm{G}$ period } \\
\hline \multirow{3}{*}{$\begin{array}{l}\text { Variable } \\
\text { EPS_Street }\end{array}$} & \multicolumn{4}{|c|}{$\begin{array}{l}\text { Post-Regulation G period } \\
(04 / 2003-2009)\end{array}$} & \multicolumn{4}{|c|}{$\begin{array}{l}\text { C\&DI period } \\
(2010-2016)\end{array}$} \\
\hline & \multicolumn{2}{|c|}{ Forced } & \multicolumn{2}{|c|}{ Voluntary } & \multicolumn{2}{|c|}{ Forced } & \multicolumn{2}{|c|}{ Voluntary } \\
\hline & -2.282 & $(0.000)$ & 0.328 & $(0.500)$ & -0.338 & $(0.577)$ & -0.063 & $(0.891)$ \\
\hline Exclusions & -0.975 & $(0.076)$ & -0.336 & $(0.402)$ & -0.499 & $(0.374)$ & -0.022 & $(0.957)$ \\
\hline For_Rev & 1.315 & $(0.223)$ & -1.408 & $(0.078)$ & -0.126 & $(0.914)$ & -1.717 & $(0.027)$ \\
\hline Ret_Idio & -0.720 & $(0.000)$ & -0.229 & $(0.072)$ & -0.936 & $(0.000)$ & -0.261 & $(0.047)$ \\
\hline Ret_Peer & 0.055 & $(0.897)$ & -0.127 & $(0.648)$ & 0.298 & $(0.564)$ & -0.144 & $(0.650)$ \\
\hline Std_Ret & 1.747 & $(0.239)$ & 1.143 & $(0.283)$ & 2.176 & $(0.162)$ & 2.751 & $(0.009)$ \\
\hline $\log M V E$ & 0.006 & $(0.916)$ & 0.047 & $(0.203)$ & -0.027 & $(0.600)$ & 0.074 & $(0.022)$ \\
\hline$M T B$ & 0.024 & $(0.737)$ & 0.037 & $(0.442)$ & -0.030 & $(0.637)$ & -0.109 & $(0.017)$ \\
\hline$S G R$ & -0.385 & $(0.271)$ & -0.157 & $(0.521)$ & -0.231 & $(0.488)$ & -0.578 & $(0.012)$ \\
\hline$L E V$ & -0.213 & $(0.632)$ & -0.017 & $(0.953)$ & 0.150 & $(0.684)$ & -0.168 & $(0.497)$ \\
\hline CEO_Age & -0.095 & $(0.000)$ & 0.123 & $(0.000)$ & -0.134 & $(0.000)$ & 0.120 & $(0.000)$ \\
\hline CEO_Owner & -0.049 & $(0.079)$ & -0.091 & $(0.000)$ & -0.088 & $(0.002)$ & -0.099 & $(0.000)$ \\
\hline CEO_Dual & 0.068 & $(0.664)$ & 0.214 & $(0.049)$ & -0.086 & $(0.568)$ & 0.016 & $(0.857)$ \\
\hline Year indicators & \multicolumn{4}{|c|}{ Yes } & \multicolumn{4}{|c|}{ Yes } \\
\hline Industry indicators & \multicolumn{4}{|c|}{ Yes } & \multicolumn{4}{|c|}{ Yes } \\
\hline Pseudo-R ${ }^{2}$ & \multicolumn{4}{|c|}{$11.45 \%$} & \multicolumn{4}{|c|}{$11.90 \%$} \\
\hline Cases of turnover & \multicolumn{2}{|c|}{213} & \multicolumn{2}{|c|}{528} & \multicolumn{2}{|c|}{253} & \multicolumn{2}{|c|}{712} \\
\hline Firm-years & \multicolumn{4}{|c|}{8,065} & \multicolumn{4}{|c|}{8,468} \\
\hline
\end{tabular}

Estimates from multinomial logistic regressions that examine the likelihood of forced and voluntary CEO turnover, based on our sample of 716 forced cases of CEO turnover $\left(F_{-} C E O_{-} T O\right)$ and 1,919 voluntary cases of CEO turnover $\left(V_{-} C E O_{-} T O\right)$ from 1993-2016. In Panel A, the sample is divided into pre- and post-Regulation G periods, with April 2003 as the cutoff point. In Panel B, the post-Regulation G period is further divided based on the issuance of Compliance and Disclosure Interpretations (C\&DI) by the SEC. The sample data on CEO turnover come from the ExecuComp database. Turnover is classified as forced based on the classification scheme proposed by Parrino (1997). The data exclude the CEO's first year in office and firms in the financial and utility sectors (SIC codes between 6000-6999 and 4900-4999). All independent variables are measured in the year before the year of the turnover. A positive (negative) coefficient indicates that an increase in the covariate increases (decreases) the probability of CEO turnover. Year and industry indicators are included but not reported. All variables are as defined in Table 3 and the Appendix. 
Table 8

What income statement components drive the difference between GAAP and street earnings?

\begin{tabular}{|c|c|c|c|c|c|}
\hline \multicolumn{6}{|c|}{ Panel A: Descriptive statistics $(\mathrm{N}=26,571)$} \\
\hline Variable & Mean & Std. & $\mathrm{P} 25$ & Median & P75 \\
\hline COGS & -1.038 & -1.038 & -1.038 & -1.038 & -1.038 \\
\hline$S G A$ & -0.258 & -0.258 & -0.258 & -0.258 & -0.258 \\
\hline Depr & -0.059 & -0.059 & -0.059 & -0.059 & -0.059 \\
\hline $\operatorname{Tax}$ & -0.023 & -0.023 & -0.023 & -0.023 & -0.023 \\
\hline$S I$ & -0.019 & -0.019 & -0.019 & -0.019 & -0.019 \\
\hline Other & -0.021 & -0.021 & -0.021 & -0.021 & -0.021 \\
\hline \multicolumn{6}{|c|}{ Panel B: Summary statistics of the cross-sectional estimates } \\
\hline Estimate & Mean & t-value & $p$-value & Median & Std. \\
\hline Intercept & -0.002 & -0.25 & $(0.807)$ & 0.005 & 0.050 \\
\hline COGS & 0.002 & 0.22 & $(0.825)$ & -0.008 & 0.054 \\
\hline$S G A$ & -0.063 & -1.07 & $(0.289)$ & -0.005 & 0.382 \\
\hline Depr & -0.201 & -1.05 & $(0.300)$ & -0.024 & 1.253 \\
\hline $\operatorname{Tax}$ & 0.115 & 1.46 & $(0.151)$ & 0.197 & 0.517 \\
\hline$S I$ & 0.968 & 18.04 & $(0.000)$ & 0.885 & 0.352 \\
\hline Other & 0.208 & 4.00 & $(0.000)$ & 0.200 & 0.342 \\
\hline Adj. $\mathrm{R}^{2}$ & 0.407 & 11.47 & $(0.000)$ & 0.362 & 0.233 \\
\hline
\end{tabular}

Panel C: Forced CEO turnovers and normal and abnormal exclusions

\begin{tabular}{lcc} 
& Model $(1)$ & Model (2) \\
\hline EPS_Street & $-1.018(0.005)$ & $-1.002(0.006)$ \\
Normal_Exclusions & $-1.447(0.004)$ & \\
Abnormal_Exclusions & $-0.722(0.061)$ & $-1.500(0.003)$ \\
SI & & $-0.734(0.045)$ \\
Other Exclusions & Yes & Yes \\
Other control variables & Yes & Yes \\
Year indicators & Yes & Yes \\
Industry indicators & $10.26 \%$ & $10.27 \%$ \\
Pseudo-R & 716 & 716 \\
Cases of turnover & 24,652 & 24,652 \\
Firm-years & & \\
\hline
\end{tabular}

Panel A reports the descriptive statistics of expense components. We disaggregate total expenses following the approach used in Donelson et al. (2011). COGS is the cost of goods sold; $S G A$ is selling, general, and administrative expenses; Depr is depreciation expenses, Tax is tax expenses; $S I$ is special items; and Other is other expenses. All variables are scaled by market value of equity. Panel B reports the summary statistics of the estimated coefficients and the adjusted R-square of 43 industry regressions from 1993-2016. Year and industry indicators are included but not reported. Industries are classified using the Fama-French 48-industry classification. The estimated model is as follows: 


\section{Exclusions $=\alpha_{0}+\alpha_{1} C O G S+\alpha_{2} S G A+\alpha_{3}$ Depr $+\alpha_{4}$ Tax $+\alpha_{5} S I+\alpha_{6}$ Other $+\varepsilon$}

Panel $\mathrm{C}$ reports the estimates from logistic regressions that examine the likelihood of forced CEO turnover, based on our sample of 716 forced cases of CEO turnover $\left(F_{-} C E O \_T O\right)$ from 1993-2016. Voluntary turnovers are excluded from the sample. Independent variables are the same as in Tables 5-7 except that in Column (1), Exclusions are replaced by the fitted value from the above regression (labeled as 'normal' exclusions) and the regression residual (labeled as 'abnormal' exclusions) values from the model above. In Column (2), Exclusions are divided into special items $(S I)$ and other exclusions (Exclusions-SI). $p$-values appear in parentheses. 


\section{Table 9}

Are street exclusions related to CEOs cash bonus?

\begin{tabular}{|c|c|c|}
\hline Variable & Tobit Model & OLS Model \\
\hline EPS_Street & $1.438 \quad(0.000)$ & $0.543 \quad(0.006)$ \\
\hline Exclusions & $1.545 \quad(0.000)$ & $0.741 \quad(0.000)$ \\
\hline For_Rev & $4.759 \quad(0.000)$ & $2.044 \quad(0.000)$ \\
\hline Ret_Idio & $0.807 \quad(0.000)$ & $0.342 \quad(0.000)$ \\
\hline Ret_Peer & $0.423(0.001)$ & $0.327 \quad(0.000)$ \\
\hline Std_Ret & $-1.328 \quad(0.017)$ & $-0.368 \quad(0.246)$ \\
\hline $\log M V E$ & $0.362(0.000)$ & $0.336 \quad(0.000)$ \\
\hline$M T B$ & $-0.156 \quad(0.000)$ & $0.003 \quad(0.873)$ \\
\hline$S G R$ & $0.556(0.000)$ & $0.574 \quad(0.000)$ \\
\hline$L E V$ & $-0.227 \quad(0.170)$ & $-0.743(0.000)$ \\
\hline CEO_Age & $0.003 \quad(0.497)$ & $-0.248 \quad(0.000)$ \\
\hline CEO_Owner & $0.118 \quad(0.000)$ & $0.022(0.005)$ \\
\hline CEO_Dual & $0.003 \quad(0.954)$ & $-0.230 \quad(0.000)$ \\
\hline Year indicators & Yes & Yes \\
\hline Industry indicators & Yes & No \\
\hline CEO-Firm indicators & No & Yes \\
\hline Firm-years & 26,571 & 26,571 \\
\hline
\end{tabular}

The dependent variable is the logarithm of one plus CEO's annual bonus (logBonus). The sample consists of 26,571 firm-year observations from 1993 to 2016. The sample data on CEO bonus come from the ExecuComp database. The data exclude the CEO's first year in office, CEO turnover unrelated to the board's decision to dismiss the CEO (death, poor health, interim appointments, mergers, spinoffs, and retirements because of old age), and firms in the financial and utility sectors (SIC codes between 6000-6999 and 4900-4999). Year and industry indicators are included but not reported. Industries are classified using the Fama-French 48-industry classification. $p$-values appear in parentheses. OLS Model standard errors are heteroskedasticity adjusted. All variables are as defined in Table 3 and the Appendix. 